Marreco

Memória

Paraíso

Cabo do

Mundo

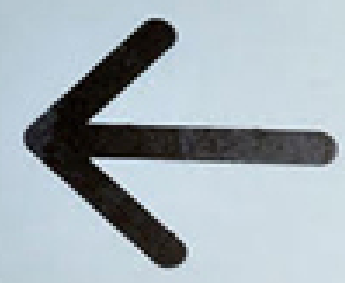

Aterro

\title{
MATERIAIS PARA O FIM \\ DO MUNDO 12
}




\section{FICHA TÉCNICA}

\section{TÍTULO}

LIBRETOS

MATERIAIS PARA O FIM DO MUNDO - 12

Maio de 2020

\section{PROPRIEDADE E EDIÇÃO}

INSTITUTO DE LITERATURA COMPARADA MARGARIDA LOSA

WWW.ILCML.COM |

VIA PANORÂMICA, S/N

4150-564 PORTO

PORTUGAL

E-MAIL: ilc@letras.up.pt

TEL: +351226077100

\section{CONSELHO DE REDACÇÃO DE LIBRETOS}

\section{DIRECTORES}

ANA LUÍSA AMARAL

ANA PAULA COUTINHO

JOANA MATOS FRIAS

MARIA DE FÁTIMA OUTEIRINHO

ORGANIZADOR DO LIBRETO № 21

PEDRO EIRAS

\section{AUTORES}

MARIA DE FÁTIMA LAMBERT

PATRÍCIA LINO

PEDRO EIRAS

\section{ASSISTENTE EDITORIAL}

LURDES GONÇALVES

\section{CAPA}

Fotografia de Pedro Eiras (placa indicativa de nomes de praias entre Leça da Palmeira e Vila do Conde).

PUBLICAÇÃO NÃO PERIÓDICA

\section{VERSÃO ELECTRÓNICA}

ISBN 978-989-54784-0-8

DOI: $10.21747 / 9789895478408 / \mathrm{fdm} 12$

OBS: Os textos seguem as normas ortográficas escolhidas pelos autores. 0 conteúdo dos ensaios é da responsabilidade exclusiva dos seus autores.

(C) INSTITUTO DE LITERATURA COMPARADA MARGARIDA LOSA, 2020

Esta publicação é desenvolvida e financiada por Fundos Nacionais através da FCT - Fundação para a Ciência e a Tecnologia, no âmbito do Programa Estratégico "UIDP/00500/2020".

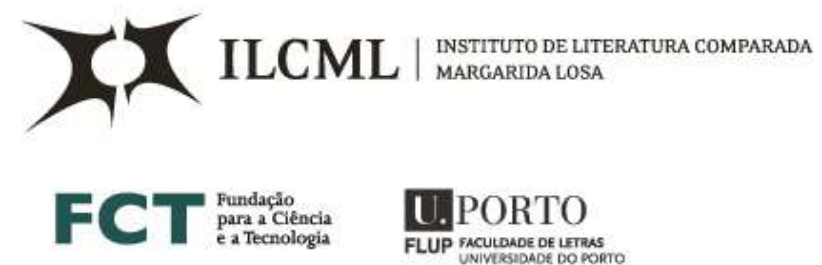


Libretos \#21

Materiais para o Fim do Mundo - 12

Org. Pedro Eiras 



\section{Nota de abertura}

No dia 21 de Dezembro de 2012, a expectativa de um fim do mundo - tão espectacular quanto improvável - foi vivida à escala planetária. Entre terrores genuínos e um irónico ambiente de festa, a data fatídica passou sem incidentes, e profecias de novas datas para uma destruição do planeta começaram imediatamente a surgir.

O que é o fim do mundo? Um juízo universal da humanidade, conforme dizem os textos vetero- e neotestamentários? Uma catástrofe ecológica, global e iminente, provocada pelo homem? A alegoria de um mundo que perdeu as suas (meta)narrativas, vogando sem verdade e sem destino, após Auschwitz e Sarajevo? O pretexto para a sedução do espectáculo, entre filmes-catástrofe e um delicioso imaginário da destruição? Ou o confronto de cada qual com a sua morte própria? Por que nos fascina e aterroriza este tema milenar, nunca resolvido - e o que temos a ganhar com a exploração do nosso próprio terror?

Para estudar o imaginário do fim do mundo, o Instituto de Literatura Comparada Margarida Losa organizou, entre 2013 e 2018, uma série de seminários abertos, coincidindo com os equinócios e os solstícios. Os libretos Materiais para o Fim do Mundo recolhem alguns ensaios apresentados nesses seminários, ou textos afins. Neste último libreto da série Materiais para o Fim do Mundo, Maria de Fátima Lambert analisa as viagens a vários confins do mundo da escritora Maria Graham Callcott (1775-1842), avaliando o que significa ser uma mulher viajante e escrever relatos de viagem, numa interminável dialéctica entre o conhecimento do estranho e o reconhecimento do familiar; Patrícia Lino retoma algumas questões do seu ensaio " «Começava, só para ti, o fim do mundo»" (Materiais para o Fim do Mundo, 1, 2014), pensando a dimensão política da poesia, a invenção e a resistência ao cânone, a criação do mundo e a observação, "empática e humilde", do mundo do outro; e eu próprio faço um saldo dos seminários realizados entre 2013 e 2018, gizando algumas conclusões possíveis, antevendo novas pesquisas a realizar.

Pedro Eiras 



\title{
[Quase] até ao fim do mundo: viajantes intrépidas
}

\author{
Maria de Fátima Lambert \\ InED - Escola Superior de Educação/Politécnico do Porto
}

Resumo: As viagens transcontinentais, ao tempo de Maria Graham, eram jornadas [quase] até ao fim do mundo. As mulheres que as empreendiam, cumpriam premissas específicas que se constata, hoje, serem manifestações identitárias ousadas, inovadoras, pois [com subtileza] transgrediam as convicções e procedimentos societários dominantes. Maria Graham não integrou qualquer missão artística ou expedição científica. Todavia a atividade que concretizou, aproxima-se (senão supera) o impacto da produção literária e visual de outros protagonistas europeus que cumpriam objetivos científicos explícitos. A autora inglesa, integrando de um panorama histórico, preenchido por figuras emblemáticas, afirmou desempenhos pessoais resilientes e lúcidos, ao envolver-se na sociedade brasileira (portuguesa), tendo-se aproximado das comunidades autóctones para, mais corretamente, entretecer as suas considerações, decorrendo da sua experiência in loco e de estudos multidisciplinares.

Palavras-chave: até ao fim do mundo, Maria Graham, viajantes intrépidas

\begin{abstract}
Transcontinental journeys, at the time of Mary Graham, were journeys towards [almost] the end of the world. The women who undertook them fulfilled specific assumptions that today are found to be bold, and being innovative manifestations of their identities because they [although subtly] transgressed the prevailing societal beliefs and procedures. Maria Graham was not part of any artistic mission or scientific expedition. However, the activity that she accomplished, approaches (if not surpasses) the impact of her literary and visual production, close to other European protagonists that fulfilled explicit scientific goals. The English woman-author, being part of a historical panorama, filled with emblematic figures, affirmed a resilient and lucid personal performances, by getting involved in Brazilian (Portuguese) society, having approached the indigenous communities to, more correctly, entertain her considerations, from their on-site experience and multidisciplinary studies.
\end{abstract}

Keywords: until the end of the world, Maria Graham, intrepid women travelers 
Stop the world I want to get out.

Sammy Davies Jr.

Todas as ânsias e inquietudes do mundo não se modificarão.

Augusto Alfred Schmidt

\section{Onde é o fim do mundo? 0 que é o fim do mundo? 0 fim do mundo é de qualquer um e é diferente.}

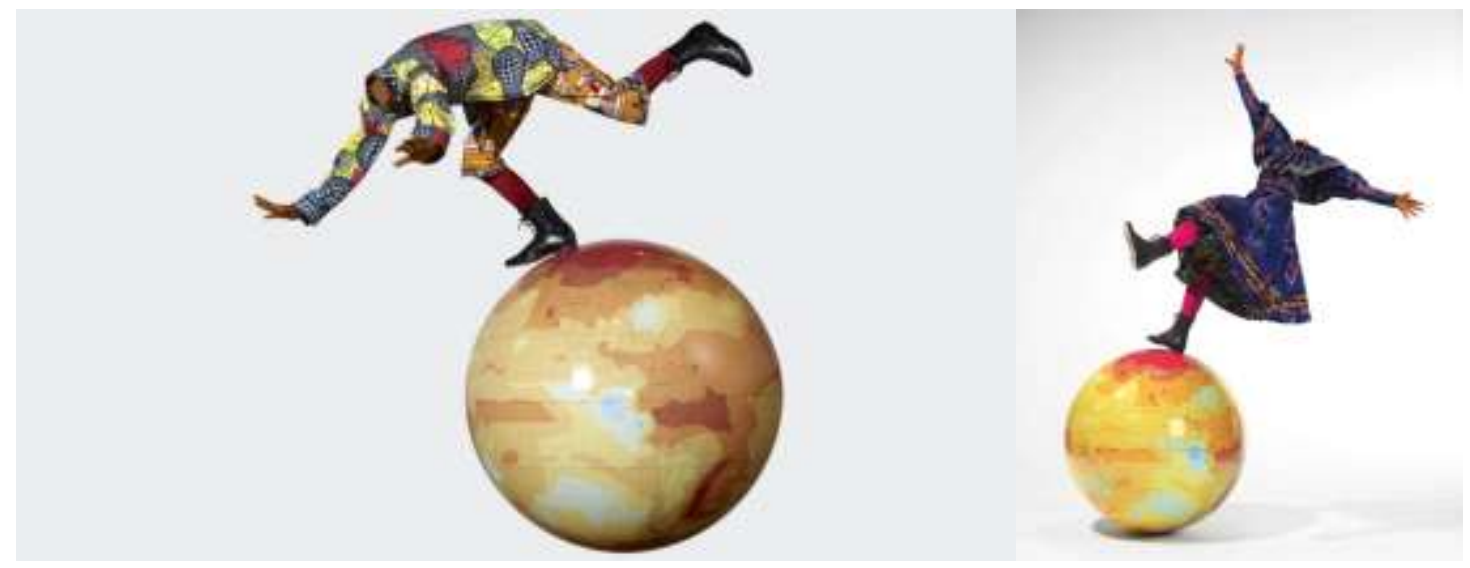

Yinka Shonibare, Boy with a Globe 4, 2011

Yinka Shonibare, Girl on Globe, 2012

A compreensão do mundo e a compreensão da Arte entretecem-se na escrita e em imagens que se indispõem ou conciliam ao longo de uma vasta literatura e de uma produção gráfica e pictórica relevante, a que se adicionaram os registos fotográficos, cinematográficos e videográficos. Na compilação de autores que aquiesceram à tendência ou compulsão por partilhar, conservar (ou apenas fruir) as suas viagens, um número muito significativo de mulheres viajantes destaca-se. A que imago do mundo se destinavam os impulsos, que efabulações ou confrontos com a realidade lhes dava réplica, que fim lhes cabia atingir? Questione-se quais mapas orientavam os itinerários, quantas vezes se mostraram insuficientes ou falseando a verdade in loco... remetendo 
para viagens históricas a um tempo em que os contornos dos continentes ainda precisavam de reconfigurar a factualidade do espaço e seu tempo.

Quais os elementos - em termos cosmogónicos - que (melhor) clamam e correspondem às representações entranhadas que elaboramos quanto ao fim do mundo; isto de acordo com as nossas pulsões, a sensibilidade primária, os tópicos filosóficos e culturais que a nossa formação imediatamente convoca: será o fogo, será a água, será a terra, será o ar? Bachelard serve muito justamente para o efeito, assim como às suas obras intrinsecamente se associará Charles Mauron e as suas Imagens Obcecantes e as derivas de Jean-Jacques Wunenburger acerca das Fontes do Imaginário e a Utopia... passando, obviamente por Gilbert Durand - Estruturas Antropológicas do Imaginário e ainda as belíssimas Iconologias, privilegiando Cesare Ripa - no relativo à representação destes Elementos e de todos os conceitos e ideias que estejam associados... e são muitos. A 15 de janeiro de 1941, Olivier Messiaen apresentou o seu Quatuor pour la Fin du Temps na Barrack 27, Stalag VIIIA, perante um público de cerca de 400 pessoas, entre prisioneiros e guardas. Estava-se em plena 2a Guerra Mundial e o compositor francês era prisioneiro de guerra no campo alemão de Görlitz (atualmente território da Polónia). Os quatro músicos foram: Henri Akoka (clarinetista), Jean le Boulaire (violinista), Étienne Pasquier (violoncelista) e o próprio Messiaen ao piano. A peça estrutura-se em 8 partes, com as designações francesas:

\footnotetext{
I. Liturgie de cristal

II. Vocalise, pour l'Ange qui annonce la fin du Temps

III. Abîme des oiseaux

IV. Intermède

V. Louange à l'Éternité de Jésus

VI. Danse de la fureur, pour les sept trompettes

VII. Fouillis d'arcs-en-ciel, pour l'Ange qui annonce la fin du Temps

VIII. Louange à l'Immortalité de Jésus
}

Olivier Messiaen e o seu Quarteto para o Fim do Tempo (1940) poderia ser uma espécie de fundo existencial para afinidades eletivas... um pouco como se fosse aquela música das esferas que Pitagóras elucidou. 0 compositor tomou como referência o Apocalipse de São João - Livro da Revelação, no seu Cap. 10:1-2 e 5-7: “Je vis un autre ange puissant, 
qui descendait du ciel, enveloppé d'une nuée; au-dessus de sa tête était l'arc-en-ciel, et son visage était comme le soleil, et ses pieds comme des colonnes de feu. (...) Et l'ange, que je voyais debout sur la mer et sur la terre, leva sa main droite vers le ciel, et jura par celui qui vit aux siècles des siècles (...) qu'il n'y aurait plus de temps..." (Le Livre de la Révélation s/d: 110). "Não haveria [mais] tempo...", no sentido de quem não se puder aguardar mais para que... até que... O tempo estaria condicionado pelas condições e circunstâncias da história. A circunscrever a ação e a obrigá-la, quer em termos individuais, quer gregários.

Clarice Lispector advertiu quanto à polissemia na sua $A$ Descoberta do Mundo, compilação das 468 crónicas escritas para o Jornal do Brasil, entre 1967 e 1973.

Ruben A., o escritor português que residiu e lecionou em Inglaterra, expressou em $O$ Mundo à minha Procura um projeto autobiográfico em 3 volumes, publicados numa primeira edição, parceria com António Maria Pereira (Lisboa) em 1964, 1966 e 1968.

\section{Imensidão do mundo | Mundo é redondo - sagrado | Mundo é em linha reta - humano}

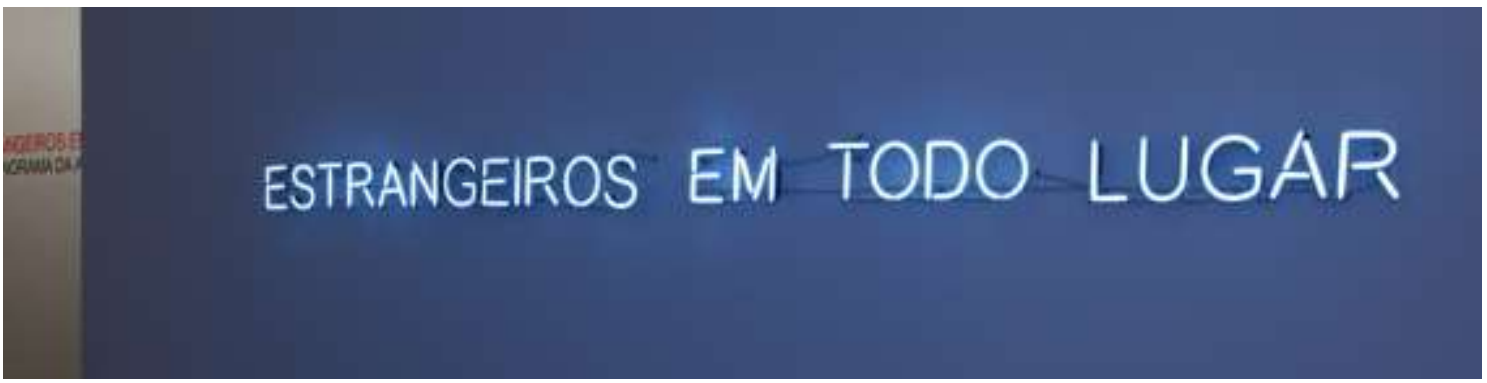

Claire Fontaine - Estrangeiros em Todo Lugar (foreigners everywhere), 2009

https://mam.org.br/exposicao/310-panorama-da-arte-brasileira/

As alusões ao fim do mundo são recorrentes na história da Arte e da Cultura [Europeias] Ocidentais, evidenciando quanto é um estigma, independentemente de prevalecerem causas religiosas e/ou sagradas. Sendo recorrentes, evocam precisamente o círculo e a esfera que contêm o dinamismo e a quietude, o comprometimento e a isenção. 0 mundo é uma bela metáfora do mito, para além de o oposto ser válido. Pois a 
linha que fecha sem começar pode estender-se, desenrolar-se e perder-se até o fim. A linha reta do mundo que é humano e cuja topografia impede seja plano. Sempre imenso, preenchido pelas incontáveis evocações que ao longo da história da cultura integraram a palavra, a ideia, a imagem, o som, o cheiro... e assim por diante de algo que se escreve: $m$ u $n d$ o. Por esse motivo, a investigação para este desafio do Seminário do Fim do Mundo, num primeiro momento, consistiu na recuperação de leituras soltas que aludiam ao mundo. A partir destas leituras, em tempo deslocado, configurou-se mais nitidamente a exigência, a convocatória da viagem que fosse (quase) até ao fim do mundo.

\section{EXCERTOS | ESCOLHAS PARA A VIAGEM 1 - Mundo que não chega ao fim ou talvez}

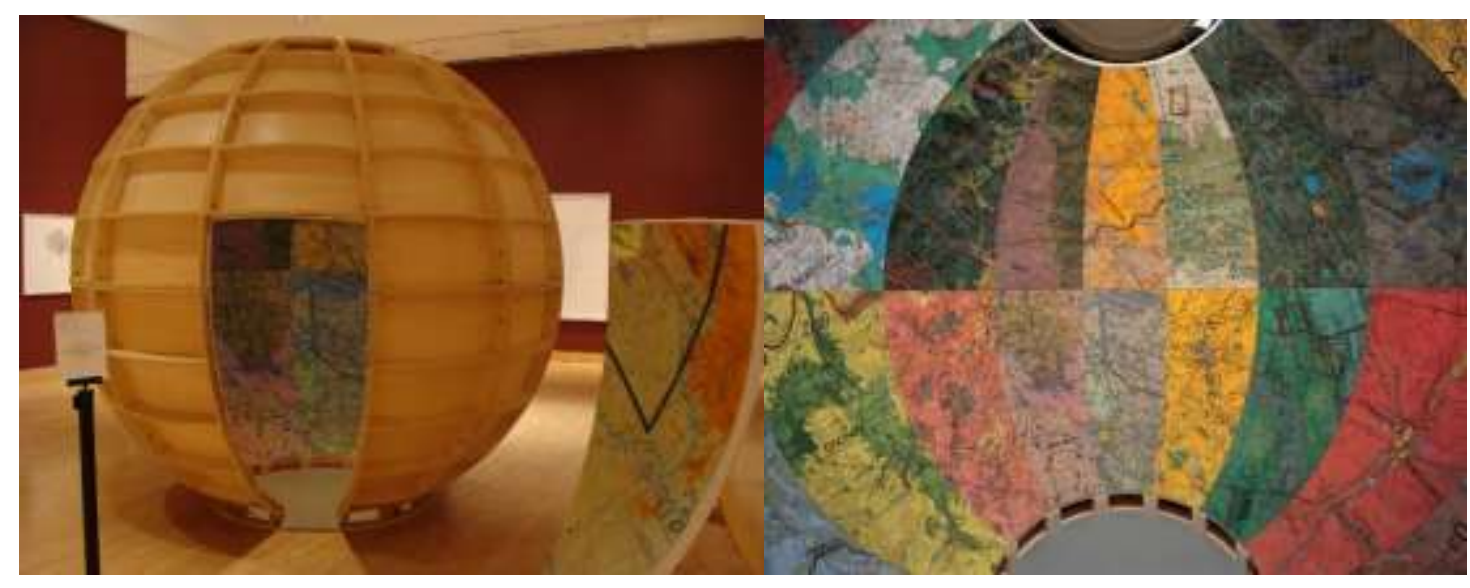

Joyce Kozloff - Targets, 2000-2003, www.joycekozloff.net/2000-2003-targets-rocking-the-cradle

Le monde nous dérobe à nous-mêmes, et la solitude nous y rend. Le monde n'est qu'une troupe de fugitifs d'eux-mêmes.

Madame de Lambert

Ainda não é o fim nem o princípio do mundo calma é apenas um pouco tarde

Manuel António Pina

O mar está sempre em movimento para não sair do lugar. Se o mar saísse do lugar teríamos de mudar os mapas.

Arnaldo Antunes 
Era a minha cidade ao norte do mapa,

numa velocidade chamada

mundo sombrio. (...)

E a seiva

sombria vinha escorrendo do mapa

desse girassol, no mapa

do mundo.

Herberto Helder

Teus ombros suportam o mundo

E ele não pesa mais que a mão de uma criança.

Carlos Drummond de Andrade

Chamar-te visão seria

malconhecer as visões

de que é cheio o mundo

e vazio

Carlos Drummond de Andrade

É como se o mundo estivesse à minha espera. E eu vou ao encontro do que me espera.

Clarice Lispector

Tudo no mundo começou com um sim. (...) Não sei o quê, mas sei que o universo jamais começou.

(...) Deus é o mundo. A verdade é sempre um contacto interior e inexplicável.

Clarice Lispector

A última casa desta aldeia está

tão só como a última casa do mundo.

Rainer Maria Rilke

Eu estou aqui

no mundo das palavras-objectos

que mudamente me falam

com quem mudamente falo

ao usá-las:

mas que uso fazem elas de mim?

Ana Hatherly 
0 mundo é grande,

incomensurável com a unidade parca de qualquer de nós. (...)

Rasgando as frágeis teias que aprendi

à minha custa e à das coisas para

criar real o mundo e os olhos que

no mundo reconhecem o real.

Jorge de Sena

Para apalpar as intimidades do mundo é preciso saber:

a) Que o esplendor da manhã não se abre com

faca

b) 0 modo como as violetas preparam o dia

para morrer

c) Por que é que as borboletas de tarjas

vermelhas têm devoção por túmulos

d) Se o homem que toca de tarde sua existência

num fagote, tem salvação

Manoel de Barros

Pois a justiça se confunde com aquele equilíbrio das coisas, com aquela ordem do mundo onde o poeta quer integrar o seu canto. Confunde-se com aquele amor que, segundo Dante, move o sol e os outros astros. Confunde-se com a nossa confiança na evolução do homem, confunde-se com a nossa fé no universo. Se em frente do esplendor do mundo nos alegrarmos com paixão também em frente do sofrimento do mundo nos revoltamos com paixão.

Sophia de Mello Breyner Andresen

Se-ducere, é conduzir à parte. De um mundo para o outro. Do porta-voz ao Outro. O sujeito está algures, o ponto incógnito inacessível ao outro.

Pascal Quignard

\section{Viagens até ao fim do mundo}

Seja referência de título de pintura, composição ou livro, seja aprofundando pressupostos filosóficos e teológicos, o fim do mundo invadiu a produção cinematográfica desde os primórdios da sua eclosão. No cinema as evidências subsumidas ou sublimadas do fim do mundo ainda são mais convincentes, ainda que 
menos ameaçadoras, pois são quase sempre propostas como ficções. Quase a roçar o final do séc. XX, surgia no circuito comercial do cinema Até ao Fim do Mundo, de Wim Wenders (1991).

Qual a sedução pelo/do fim do mundo? Entre a volúpia, a lucidez ou a escatologia que lhes esteja implícita, o que e quem advém?

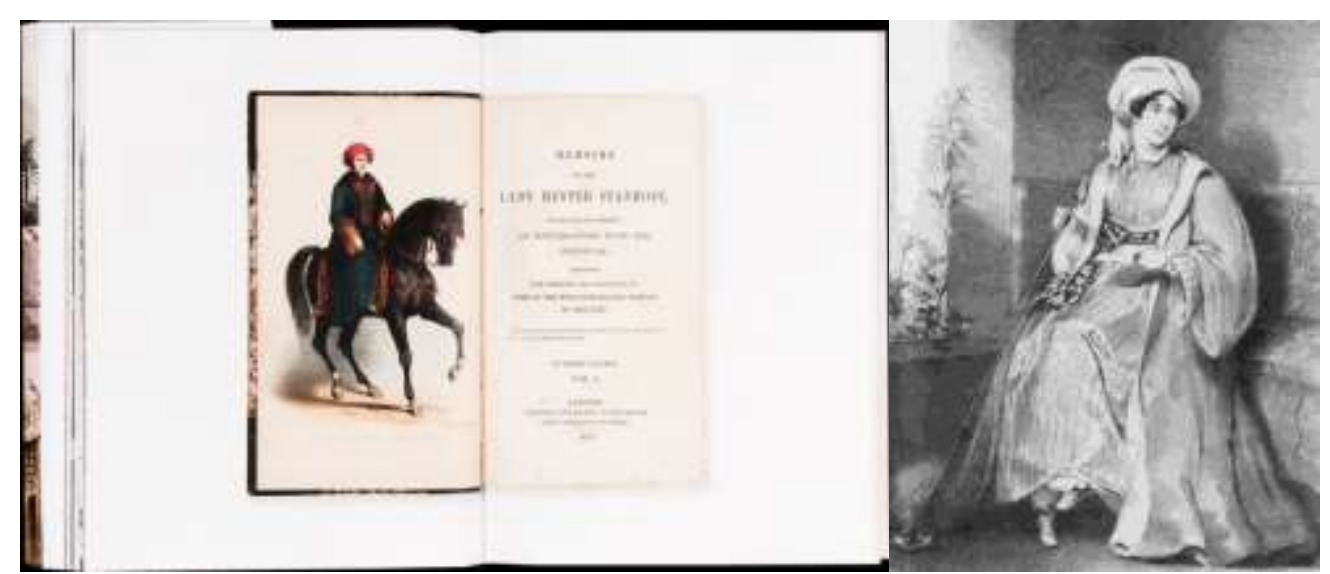

Lady Hester Stanhope in www.arcadian-library.com/study-series-no-10.php

https://wikivisually.com/wiki/Lady Hester Stanhope

\section{EXCERTOS | ESCOLHAS PARA A VIAGEM 2 - Mundo de que se avista o fim:}

Tantas imagens-associações que não posso revelar nos meus versos

Porque sou ainda muito mau poeta

Porque o universo me ultrapassa

Porque me esqueci de fazer um seguro contra os acidentes de caminho-de-ferro

Porque não sei ir ao fundo das coisas

E tenho medo

Blaise Cendrars

Quero ver o que há no mundo.

0 que resta.

0 que deitaram fora.

0 que deixou de se apreciar.

0 que teve de se sacrificar.

O que se pensou que pudesse interessar a alguém.

Susan Sontag 
0 que não deixa de fazer de todo mundo o viajante sempre em busca da outra parte, ou o explorador maravilhado desses mundos antigos que convém, sempre e ainda uma vez, inventar. Porque estar inquieto ou em desequilíbrio não é, afinal de contas, o próprio elã vital?

Michel Maffesoli

La vue sera donc l'exercice du peintre en voyage ; à moins qu'elle ne soit dessinée ou peinte par des artistes locaux pour des voyageurs désireux de conserver un souvenir de leurs surprises. Le genre est donc lié à la pérégrination, à la découverte, à l'étonnement devant un caprice ou une singularité de la nature, lorsque celle-ci paraît offrir au contemplateur une anticipation des réussites de l'art. Ce qui retient le regard, c'est le pittoresque, c'est-à-dire cette sorte de charme, répandu sur l'objet, qui demande à devenir peinture. «Si le peintre voyage, recommande Nicolas Cochin, il doit remarquer surtout les espèces d'arbres pittoresques que l'on trouve rarement dans son pays.» (...) De toutes ces choses, il faut faire des notes avec des croquis et ne jamais se fier à sa mémoire : les idées s'effacent bien facilement, si rien ne les fixe.

Jean Starobinski

\section{As viagens [que não chegam] ao fim do mundo - antes de Maria Graham}

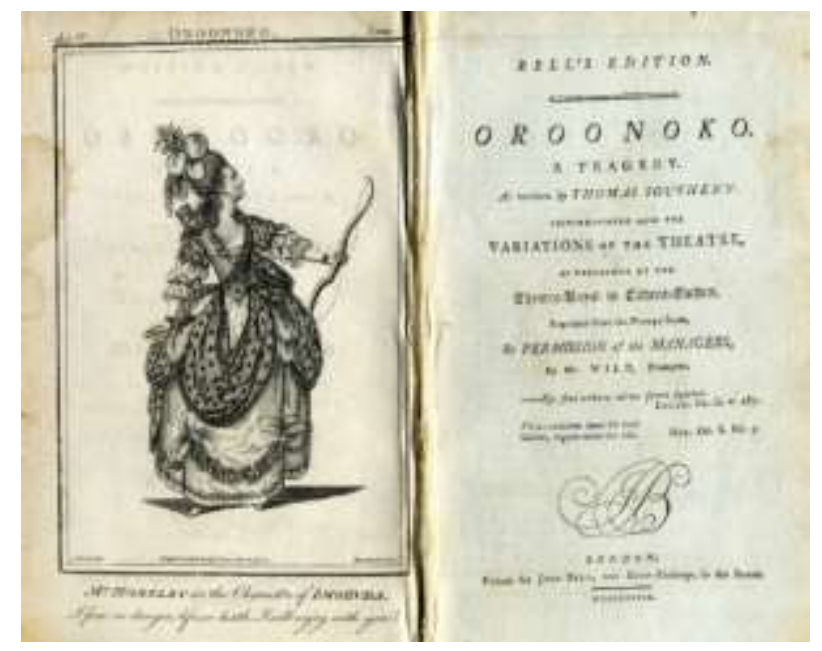

Aphra Bem, Oronoko in https://theculturetrip.com/europe/united-kingdom/england/articles/oroonokoby-aphra-behn-the-first-novel-ever-written-in-english/

Quantas e quais viagens seriam, foram ou pretendiam ser viagens desejadas até ao fim do mundo? Entre os estudos que nos últimos meses vim a desenvolver, situei-me nas viagens e nos escritos de Maria Graham Callcott. 
Mas antes, vou referir apenas alguns tópicos, que também podem servir ao debate que se venha a seguir.

Quantos e quais conceitos, ideias concomitantes assistem, concorrem para pensar Viagem até ao fim do mundo: desde as múltiplas utopias, passando pelas aceções de viagem intemporais mais díspares, desde os primórdios do que designamos por literatura de viagens e suas redenções ou indexações filosóficas e culturais. Obviamente, todos estes conceitos cavalgando às costas do mundo ou carregando este mundo que é um globo nas omoplatas de Atlas. Atenda-se à riqueza, a quanto prolifera a iconografia de Atlas na História da Arte Ocidental, a quanto seduz as filosofias e estéticas do imaginário, devidamente radicadas em antropologias culturais simbólicas, iconologias e demais exigências de conhecimento e criação.

A ideia de mundo (intangível versus tangível) e a ideia de Atlas (globo, esfera) alastram pela criação moderna e contemporânea, sob auspícios quase insuspeitos que indiciam a necessidade, a compulsão mesmo, para arquivar, inventariar, catalogar os seus infinitos conteúdos - quer materiais, quer imateriais, roçando entre o que se guarda à mão cheia e o que a intangibilidade permeia.

Circum-navegar implica conceitos dominantes: viagem, périplo, cartografia do mundo, saiba-se o que por este se entende ou não... Supõe um traçado dominado pela forma circular, tendo a certeza de o mundo ser redondo. 0 mundo que é o planeta Terra. Jean-Marc Besse em Le Goût du Monde...

Quando alguém empreendia viagens extensas, com escopo de alcançar o mundo, de seu princípio ou meio até ao fim, acreditava na sua circularidade, desconhecendo-lhe o diâmetro... O imaginário como motor conceptual na cartografia europeia (e não só) foi prevalecente durante séculos. Os mapas eram configurados por indivíduos, que não necessariamente empreendiam as grandes viagens, antes se faziam visitar, recebiam aqueles que as haviam efetuado e, a partir de seus relatos, desenhavam os contornos e espessavam as topografias.

Quem viajava? Atenda-se ao que reflexiona Jean-Jacques Rousseau em Discours sur l'Inégalité (1754), atendendo ao passado histórico das viagens na Europa:

Depuis trois ou quatre cents ans que les habitants de l'Europe inondent les autres parties du monde et publient sans cesse de nouveaux recueils de voyages et de relations, je suis persuadé 
que nous ne connaissons d'hommes que les seuls Européens; encore paraît-il aux préjugés ridicules qui ne sont pas éteints, même parmi les gens de lettres, que chacun ne fait guère sous le nom pompeux d'étude de l'homme que celle des hommes de son pays. Les particuliers ont beau aller et venir, il semble que la philosophie ne voyage point, aussi celle de chaque people est-elle peu propre pour un autre. La cause de ceci est manifeste, au moins pour les contrées éloignées: il n'y a guère que quatre sortes d'hommes qui fassent des voyages de long cours; les marins, les marchands, les soldats et les missionnaires. Or, on ne doit guère s'attendre que les trois premières classes fournissent de bons observateurs et quant à ceux de la quatrième, occupés de la vocation sublime qui les appelle, quand ils ne seraient pas sujets à des préjugés d'état comme tous les autres, on doit croire qu'ils ne se livreraient pas volontiers à des recherches qui paraissent de pure curiosité et qui les détourneraient des travaux plus importants auxquels ils se destinent. (Rousseau 1754: 95)

Viajar não necessariamente significa conhecer os demais que não os Europeus que se voltavam sobre os seus próprios desígnios, menosprezando ou valorizando o que lhes era estranho - mesmo quando se consideravam os homens de letras, os intelectuais. Haveria apenas quatro tipos de homens que faziam viagens, reafirme-se seguindo JeanJacques Rousseau:

1. Marinheiros;

2. Comerciantes;

3. Soldados;

4. Missionários.

E o que dizer, então, acerca da caraterização tipológica de mulheres que deliberavam e se lançavam nessas viagens tão longas e ousadas?

Retrocedam-se séculos, invocando o Itinerarium cumprido por Egéria Pellegrinaggio di Egeria in Terrasanta (séc. V d.C.), cerca de 900 anos antes de que fosse escrito Ascensão ao Monte Ventoso (1336), pelo poeta italiano Petrarca ${ }^{1}$. 0 registo literário de Petrarca abrange detalhes denotativos de uma acuidade contemplativa que mereceu elaboração posterior, entrecortado por certos imediatismos estéticos. É uma caminhada estética, como já antes a considerei. É um roteiro de proximidade, cuja distância se mede em horas. A obra notável de Egéria, a sua viagem/missão mede-se com os riscos de uma duração imprevisível e marcada pela ousadia e pelo risco. 0 tempo 
demorou-se para cumprir o itinerário. Trata-se de uma mulher-monja que viveu nos primeiros tempos do Cristianismo legitimado por Roma, tendo deliberado e concretizando uma travessia até aos Lugares Santos. Façanha empreendida à semelhança de outras pessoas, designadamente, algumas mulheres.

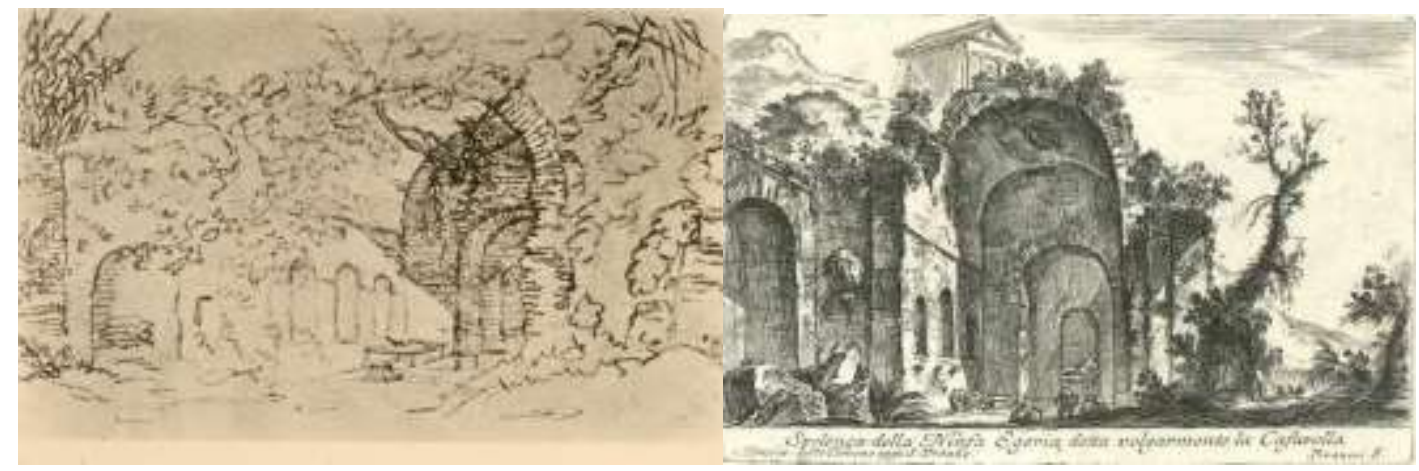

Goethe, Gruta de Egéria, www.goethezeitportal.de/wissen/projektepool/goethe-italien/rom/rom-inalten-ansichten/rom-egeria.html

Giovanni Battista Piranesi: Spelonca della Ninfa Egeria,

www.goethezeitportal.de/wissen/projektepool/goethe-italien/rom/rom-in-alten-ansichten/romegeria.html

Egéria legou a sua experiência em primeira voz intermediada pela distância do tempo, num período em que preponderava a cultura latina. Egéria pertencia a uma classe alta, pelo que conheceria o latim. A sua escrita demonstrava um estilo literário cuidado, aferido aos determinismos da época, como assinalou Bruno Fregni Bassetto no prefácio à versão brasileira do livro (cf. Egéria 2017: 13; havia por certo textos anteriores ao de Egéria, como se pode ler no prefácio citado). Séculos mais tarde, Goethe quando da sua viagem a Itália escreveria, perante a famosa Gruta que tomou o nome da viajante: "Heut' hab' ich die Nymphe Egeria besucht, dann die Rennbahn des Caracalla, die zerstörten Grabstätten längs der Via Appia und das Grab der Metella, das einem erst einen Begriff von solidem Mauerwerk gibt. Diese Menschen arbeiteten für die Ewigkeit, es war auf alles kalkuliert, nur auf den Unsinn der Verwüster nicht, dem alles weichen mußte" (1786). A figura era de tal modo emblemática que desenhou o local, numa das suas belas criações visuais que acompanharam estes seus escritos.

As condições da viagem empreendida por Egéria são notáveis (e invulgares) no contexto da época. Somente alguém procedendo, não apenas de uma classe abastada, 
mas de uma família privilegiada, teria acesso a apoios e proteção nos termos em que teve. Viajava acompanhada por uma escolta e teria tido mesmo direito a guarda imperial, durante alguns trajetos. Por outro lado, quanto à sua escrita em latim, os investigadores colocaram dúvidas que têm vindo a ser colmatadas. Numa introdução recente à edição crítica, traduzida para português e publicada no Brasil, Maria Cristina Martins assinala que no período subsequente à legitimação do Cristianismo, o Império não abdicava de que o latim fosse a língua vigente e dominante.

Egéria terá realizado 4 viagens ${ }^{2}$ :

- Peregrinação ao Monte Sinai e regresso a Jerusalém pela terra de Gessen - teria partido do Egipto;

- Peregrinação ao monte Nebo, onde queria contemplar, à semelhança de Moisés, a Terra Prometida;

- Peregrinação à Idumeia, país de Jó;

- Peregrinação à Mesopotâmia e regresso a Constantinopla, passando por Tarso, Selêucia e Calcedónia.

Num tempo tão longínquo, em que se pensaria improvável mulheres empreenderem tais viagens, as interrogações persistem: que ideia tinham do mundo, qual a sua extensão metafórica ou fatual, que impulsos as direcionavam (quase) até ao fim do mundo.

Porque viajamos? Por que vamos assim pelas estradas, tomados de delírio vagabundo, experimentando a sensibilidade sobre as obras que não buscamos apenas, mas que, sobretudo, trocamos por um lugar na grande confraria da cultura? Uma viagem não deve ser unicamente um recreio de amantes ou um preconceito de burgueses, mas deve conter uma proposta de embaixador e um pensamento que frutifique. (Bessa-Luís 2009: 187)

As narrativas de viagem, as anotações que as propiciam, obrigam a um exercício suplementar, quer os registos aconteçam no decurso dos trajetos, quer sejam invocados após um regresso, ou pelo menos, quando uma permanência mais demorada se ocasione. Os conteúdos, que se imagina sejam verídicos, transmitem tópicos, situações e fatos reais, acontecidos. Ao serem transcritos, o exercício de rememoração acrescentalhes, retira-lhes ou reequaciona dados e suscita outras vivências. De algum modo, como 
a maioria dos atos de escrita, quando o enfoque desce sobre a experiência presencial da passagem, de atravessamento de lugares, culturas e pessoas, amplia-se, intensifica-se mais ainda. Distanciar-se-á tanto para quem vivenciou a viagem, como obviamente para quem dela obtenha conhecimento intermediado. Os relatos têm um fundamento real, mas nunca podem ser análogos, idênticos ao vivido - mesmo para quem foi o protagonista-autor-direto. Numa certa perspectiva, os relatos baseados em acontecimentos e situações vividas/presenciadas são sempre algo imaginados e fictícios. Por outro lado, considerem-se os "relatos [mesmo e grandemente] fictícios" que empolgam os leitores, ao proporcionar-lhes a promessa de suas viagens imaginárias, fabulosas, irreais. A literatura ficcionada de viagens proliferou, configurando uma tipologia de leitura dominante, alimentada por inúmeros escritores que cativou e serviu de referência a inúmeras criações artísticas, em diferentes registos e dispositivos. A adesão à literatura de viagens divide-se entre aqueles que são autores e quem seja leitor. No caso, penso que a ponderação e ajuizamento quanto aos conteúdos relatados de viagens, argumentados ou refletidos por mulheres e homens possuem denominadores comuns, mas necessariamente integram elementos distintivos, ou pelo menos absorvidos de modo diferente em alguns aspetos.

Nas viagens mais remotas, numa Europa onde o desconhecimento persistia (dominava), e as restrições de género delimitavam comportamentos estanques, as mulheres - com ímpeto para viagem - tiveram de ponderar os termos de seu reconhecimento societário: serem vistas como mulheres que eram, ou disfarçadas parecendo homens. Conhecem-se casos de mulheres europeias que viajaram assumindo figura masculina, entre as quais, no séc. XVI, a espanhola Catalina de Erauso (1592 - c. 1626), nascida no país Basco e conhecida por Monja Al Farez, que em 1615 atravessou o Oceano, tendo viajado pelo Perú e pelo Chile, Cordilheira dos Andes... Teve uma vida atribulada, quando Espanha era o Grande Império do Mundo.

Aphra Behn (1640-1689) (cf. Todd 2000), nascida em Inglaterra, inventou-se uma família e história de infância, casou com um traficante de escravos que morreu apenas um ano depois em 1665. Era uma espécie de agente secreta, tendo denunciado no seu romance Oronoko a condição dos escravos no Suriname, a tirania dos europeus, sendo um testemunho em primeira voz quanto à situação dessa colónia inglesa. 
Isabel Godin des Odonais (1727-1792), de origem peruana, casou muito jovem com Jean Godin que narraria a sua vida heroica no livro Relation du Voyage de Madame Godin, son épouse em 1778, após a sua morte. Em 1769 organizou uma expedição que tinha como objetivo atingir o Atlântico, descendo o rio Amazonas e seus afluentes. Foi uma catástrofe e foi graças à sua determinação que conseguiu sobreviver.

Jeanne Baret (1740-1807) embarcou como membro da tripulação de Louis Antoine Bouganville, sendo a primeira mulher a cumprir uma viagem de circunavegação, ainda que disfarçada de homem, vestida com trajes masculinos.

Hester Stanhope (1776-1839), igualmente trajada como homem, chefiou uma primeira missão arqueológica na Terra Santa.

Estas viajantes integram a lista de viajantes destemidas assinaladas por Alexandra Lapierre e Christel Mouchard em Elles Ont Conquis le Monde.

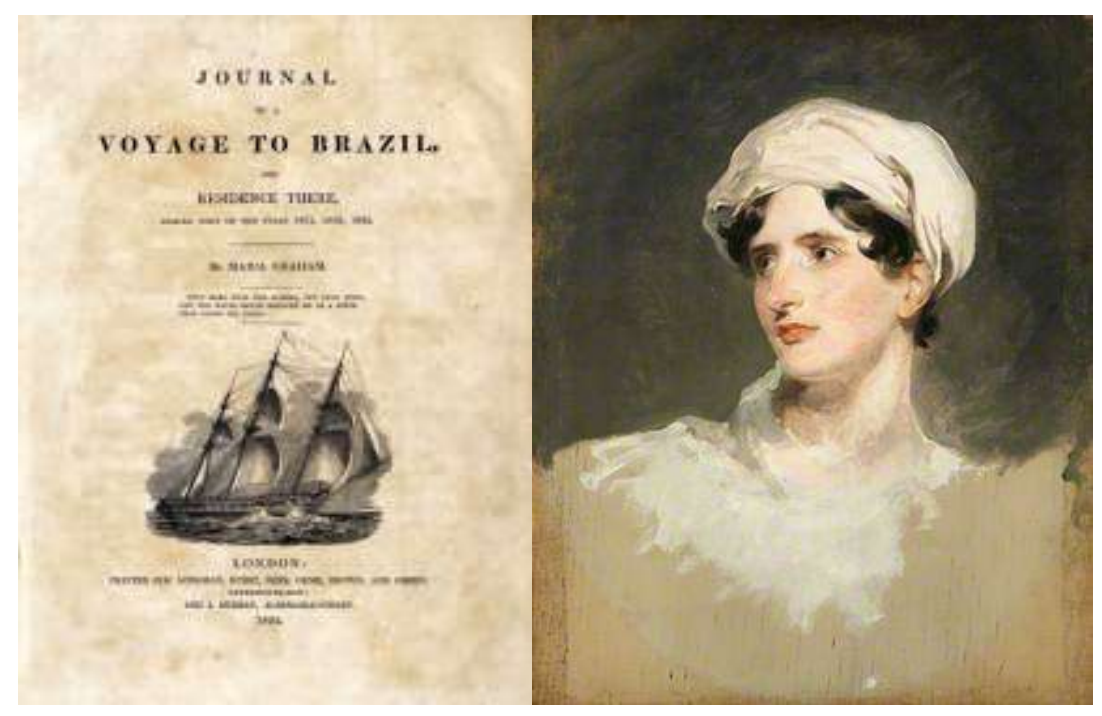

Maria Graham, Journal of a voyage to Brazil, and residence there, during part of the years 1821, 1822,

$\underline{1823}(1824)$

Sir Thomas Lawrence, Portrait of Maria Graham, 1819

Maria Dumbas Graham Callcott (1775-1842), curiosamente, não é abordada, não sendo alvo de qualquer menção neste livro, cujo título lhe "assentaria como uma luva": Elles Ont Conquis le Monde. Aliás, nas listas de mulheres europeias viajantes tampouco é referenciada. 0 que acalenta mais ainda o fato de ser um caso emblemático, associandose às suas viagens, toda uma atividade notável e prolífera, quer como escritora, quer 
como ilustradora das suas inúmeras publicações, mas também como alguém ciente de problemáticas sociológicas e antropológicas nesse mundo vivido na transição entre o séc. XVIII e as primeiras décadas do séc. XIX.

Por certo que esta artista-viajante não é citada em Intrépidas Viajantes Vitorianas $^{3}$, onde se alude aos respetivos episódios históricos, por lhes ser anterior. 0 que lhe confere, aliás, um maior e precoce arrojo, ousadia ou intrepidez. Antecipa e torna premonitória - para as gerações que lhe sucedem - a policronia e polimorfia da sua vida.

Maria Graham não integrou qualquer missão artística, como ocorrera com artistas europeus que a precederam no Brasil, assim como com outros que lhe sucederam. Todavia a atividade concretizada pela autora inglesa em muito se assemelha à produção quer literária, quer visual desses outros protagonistas que cumpriam objetivos científicos e culturais, através de desempenhos pessoais que os envolviam na sociedade brasileira (portuguesa) e aproximavam das comunidades autóctones.

Attilio Brilli em Quando Viaggiare Era un'Arte. Il romanzo del Grand Tour menciona a proliferação de livros que pretendem fornecer orientações e prescrever um receituário para quem quisesse adentrar-se ao Grand Tour: "Non sorprendra allora se consideriamo quello del lettore en viaggio nel viaggio e si gli forniamo alcune utili informazioni sul percorso" (1995: 7).

Que tipos de viagem almejam o fim do mundo? Podemos considerar as viagens como veículos, estratégias, meios de atingir o fim do mundo concebido pelos respetivos viajantes - quer mulheres, quer homens? Relembrem-se duas taxionomias que diferenciam os viajantes.

Jacques Lacarrière distingue (1997: 20ss) aqueles(as) que viajam em três categorias:

- "voyageans": a pessoa que se desloca pelo seu trabalho mais do que por prazer;

- "voyagé(e)": o não-aventureiro do mundo moderno;

- "voyageur": o que, ao deslocar-se, vive a experiência; instrui-se e enriquece-se, à imagem de Ulisses que regressou a Ítaca, rico de tudo aquilo que adquiriu na proposta da verdadeira viagem.

Nietzsche, por sua vez, mais de um século antes do francês, em Le Voyageur et son Ombre estabelecera 5 níveis ou 5 graus, para definir os viajantes: 
- 1o grau: "sont les voyageurs que l'on voit, - à vrai dire on les voyage et ils sont aveugles en quelque sorte";

- 2o grau: "les suivants sont ceux qui regardent véritablement le monde";

- 3ํㅡㅁau: "au troisième degré il arrive quelque chose au voyageur par suite de ses observations";

- 4o grau: "les voyageurs retiennent ce qu'ils ont vécu et ils continuent à le porter en eux";

- 5o grau: considerado, portanto, o estádio supremo é aquele atingido por alguns "homens [e mulheres, acrescentaria eu] de força superior que, necessariamente acabam por exibir à luz do dia, tudo o que viram, depois de terem vivido e assimilado; eles revivem, então, as suas viagens em obras e em ações, quando regressaram a casa". (Nietzsche 1902: 146-147)

As viagens interessam aos historiadores por diferentes motivos relacionados, qualificativos e caraterizadores. Sylvie Venayre, em Panorama du Voyage - 1780-1920 (2012: 15), procede à história das viagens realizadas a partir do Ocidente:

- Viagens de conhecimento: "voyage savant";

- Viagens e meios de transportes;

- Viagens de peregrinação;

- Viagens de Turismo.

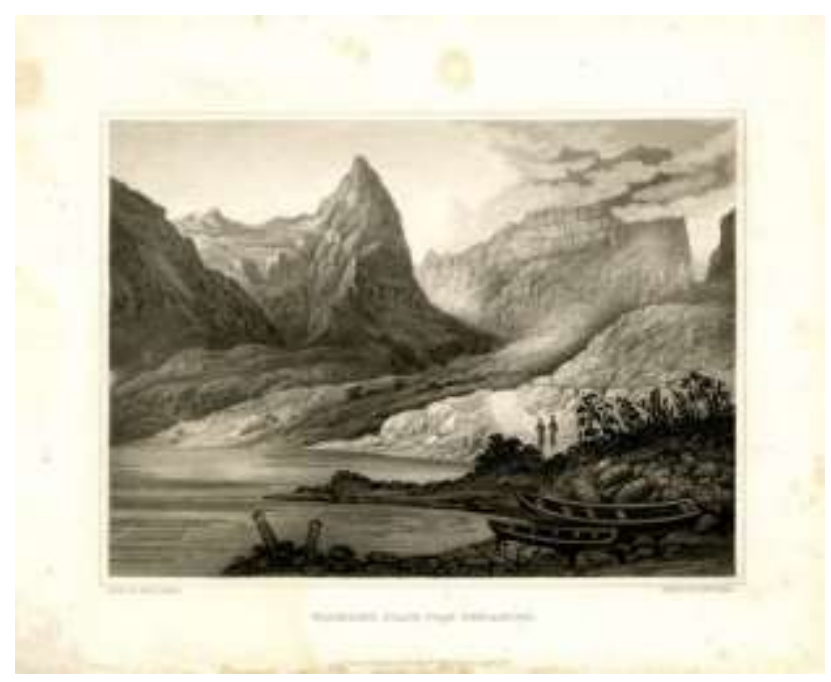

Edward Finden a partir de Maria Graham, Watering Place Juan Fernandez, Journal of a Residence in Chile, 1824

Destaquem-se alguns dos aspetos, numa perspetiva mais pormenorizadamente focada, que contribua para a abordagem ao caso de Maria Graham / Lady Callcott: 
- as colonizações iniciarem-se com o advento das viagens exploratórias;

- os objetivos das viagens: expedições científicas; artísticas; de formação; de fruição e lazer (em aceções obviamente do que atualmente e ao longo do séc. XX se estabeleceu em termos definitórios desses conceitos);

- as dificuldades dos viajantes com as línguas, os idiomas - seu desconhecimento;

- primeiros "Guias de Viagens": antes e depois da eclosão do conceito de "Turismo" - Le Tour $d u$ Monde, Libraire Hachette, 1860;

- a evolução dos transportes - vias e tipologias:

- A pé: caminhadas, peregrinações, deambulações - trajetos espontâneos ou estabelecidos "ponto de fuga na paisagem";

- Caminhos-de-ferro: redes na Europa e para fora dela, adentrando-se em outros países por via terrestre - existência de Guias de Conduta para os viajantes ferroviários; utopistas ligação de culturas > conciliação entre Ocidente e Oriente, por exemplo Saint-Simonistas;

- Rodoviários: os mitos utopistas da "estrada" como fuga, evasão - segurança e dificuldades nos caminhos;

- Marítimos/Navegação: somente a partir de 1880 se começam a empreender as "viagens transatlânticas", para viajantes que não estivessem envolvidos, mais ou menos diretamente, em objetivos / exigências profissionais ou situacionais.

Viajar, ao tempo de Maria Graham Callcott, implicava não somente a possibilidade de risco e do inesperado, mas a consciência de que fosse mesmo uma certeza. Todavia, nada a impediu de empreender e concretizar todas aquelas viagens que a indiciam como figura incontornável na cultura europeia e do Brasil no séc. XIX: "Exploring is delightful to look forward to and back upon, but it is not comfortable at the time, unless it be of such an easy nature as not to deserve the name" (Butler 1872).

- As mulheres viajantes pertenciam, maioritariamente, a classes abastadas e privilegiadas, senão financeiramente, em termos intelectuais;

- Seguindo Nicolas Bourguinat, há que distinguir as mulheres viajantes dos países protestantes atentas à intolerância religiosa e excessos de devoção nos países católicos, por exemplo; relativamente ao que seria a acutilância de olhar e ajuizamento, por parte das mulheres que procediam de países católicos - Maria Graham relata muitas situações protagonizadas por figuras do clero - retrata-os, assim como descreve situações de culto e determinações normativas da Igreja (Venayre 2012: 12);

- As viagens realizadas por mulheres aconteciam por motivo de acompanharem pais, família ou marido e podiam cumprir percentualmente os seguintes propósitos: 
- Formação;

- Estudos;

- Lazer;

- Ambiguidade do olhar feminino evidenciada na forma de escrita - livros diários, cadernos de viagens - carregava estereótipos, mas ao mesmo tempo tinha clarividência para denunciar as situações; uma noção de superioridade implícita nas mulheres europeias, por ex. as inglesas relativamente aos territórios colonizados (cf. Rogers 2008);

- As mulheres-autoras europeias demonstravam empatia quanto à condição feminina das escravas e demais situações vividas por mulheres autóctones - empatia pelo Outro que era dominado, subjugado;

- Viagem feminina como auto- e redescoberta de si: vivências, experiências vividas durante a própria viagem; a necessidade de superar os condicionalismos e as adversidades implícitas > espécie de processo de reabilitação de si;

- Emergência identitária de um "eu" feminino através da escrita e da prática do desenho e da pintura.

- A diferenciar no caso da escrita:

- Diários;

- Cartas;

- Ensaios;

- Anotações.

- A diferenciar no caso das artes visuais:

- o desenho de carácter científico - por exemplo o desenho de espécies botânicas, da flora dos trópicos, casos de Sybilla Mérien (1647-1717) ou de Marianne North (1830-1890) mas, na cronologia entre ambas, o caso de Maria Graham;

- o desenho ilustrativo de paisagens e situações vivencias na sociedade - predominando um gosto pela representação "pitoresca" - denominador comum à evidência estética iconográfica afeta, subjacente ao Grand Tour;

- "A ascensão de uma escrita feminina de viagem relaciona-se com a subjetividade ocidental, e mais em particular devido à transição do período iluminista para o romantismo, com o nascimento do 'íntimo' e da exploração do 'eu'” (Venayre 2012: 13);

- Uma curiosidade inata e uma capacidade de atender a pormenores próprios às mulheres que assim detetavam aspetos por vezes "invisibilizados"; associavam-se estas qualidades para 
observação e reconhecimento de normas, costumes e padrões de comportamento expressos em relatos e/ou narrativas específicas; designadamente uma sensibilidade que se expandia no entendimento das categorias estéticas do belo, do pitoresco e da "cor local". Não sem que, em alguns casos, a dimensão sublime seja manifesta;

- Constituição de uma noção autoral identitária, concretização mediante um envolvimento empírico, cruzado pelo acesso a dados de natureza científica, por procedimento autodidático e eivado - talvez inicialmente - de um diletantismo, que se converteu, em alguns casos, em conhecimentos epistemológica e metodologicamente validados - construção de conhecimento rigoroso - como se pode constatar nas obras de incursão na história de arte que Maria Graham publicou depois do seu segundo casamento e aquando de novas viagens pela Europa:

On n'a fait qu'accompagner un époux, on n'a de toute façon jamais quitté son foyer par l'esprit (et la lettre n'est-elle pas alors la prévue la plus tangible que le lien n'était pas rompu?). Et d'autre part, on n'avait pas l'intention immodeste de publier ces textes de circonstance, on y prendra d'ailleurs pas la parole à titre personnel, mais on y évitera au contraire toute prise de position trop tranchée, trop individuelle - dans ce cas, la correspondance privée laisse (par rapport au récit de voyage classique) une liberté de ton et une marge d'appréciation plus facilement tolérables, autant face à la censure policière, là où elle existe, que face à celle d'opinion. (Bourguinat 2008: 11)

Segundo Alexandra Lapierre e Christel Mouchard (2015: 15), as grandes viajantes e exploradoras teriam surgido em meados de oitocentos. Antes, como se referiu, tais aventuras já haviam ocorrido, embora, em muitos casos, escondendo a condição de serem mulheres. Tal não ocorria, por certo, quando viajavam acompanhando a família ou os maridos. Embora em determinadas situações tivessem tido de ocultar a sua identidade, por questões de segurança.

No caso de Maria Graham, as suas viagens estiveram quase sempre associadas a figuras masculinas. Primeiro o pai, depois os seus dois maridos. Na sua primeira viagem à Índia acompanhou o pai que ia assumir um novo cargo administrativo. Durante essa viagem conheceu aquele que viria a ser o seu primeiro marido, Robert Graham, com quem viajaria na Europa e para a América do Sul. Todavia, por morte deste, mesmo antes de atracar a Santiago do Chile, teve de regressar a Inglaterra sozinha e, depois, a convite do Imperador D. Pedro, voltou também sem acompanhante ao Brasil, onde fora convidada a ser preceptora da futura rainha D. Maria II. Aí permaneceu até 1825, dando continuidade às suas pesquisas e escritas. Após uma breve estadia em Inglaterra, 
jornadeou de novo pela Europa e Médio Oriente com o segundo marido, o pintor Sir August Callcott.

Esta autora, incomparável viajante na sua geração, teve longa permanência no Brasil. Foi uma das primeiras vozes a alertar, a expressar os perigos do etnocentrismo, do sociocentrismo no Brasil: "Les hommes sont les mêmes partout; leur opinion sur celui qu'ils jugent se mesure presque toujours d'après la position où il se trouve. L'homme heureux a toujours raison et cela dans la vie privée comme dans la vie publique. Avec plus ou moins de modifications, l'esprit de partialité et l'injustice dominent chez les nations, et plus obstinément dans certaines classes de la société" (TAl, I, 250) (cf. Pereira 1990).

Eis a listagem das suas publicações:

Obras assinadas como Maria Graham:

1. Journal of a Residence in India, A. Constable, Edimburgo, 1812. Longman, Edimburgo (2 ${ }^{\underline{a}}$ ed., 1813). (Tradução francesa de A. Duponchel na Nouvelle Bibliothèque des Voyages, Paris, 1841).

2. Letters on India, with etchings and a map. Londres, 1814.

3. Memoirs of the War of the French in Spain (traduzido do francês por M. C.) John Murray, Londres, 1815.

4. Three Months Passed in the Mountains East of Rome During the year 1819. Longman, Londres, e Constable, Edimburgo, 1820.

5. Memoir of the Life of Nicholas Poussin. Longman, etc., Londres, e Constable, Edimburgo, 1820.

6. Journal of a Voyage to Brazil and Residence There During Part of the Years 1821, 1822, 1823. Longman, etc., e John Murray, Londres, 1824.

7. Journal of a Residence in Chili During the Year 1822 and a Voyage from Chili to Brazil in 1823. Longman, etc., e John Murray, Londres, 1824.

8. Voyage of H. M. Blonde to the Sandwich Islands in the Years 1824-1825 under Captain the Right Hon. Lord Byron, Commander, 1826.

9. Escorço Biográfico de Dom Pedro I, com uma Notícia do Brasil e do Rio de Janeiro. (Tradução de Américo Jacobina Lacombe). Rio de Janeiro, Anais da Biblioteca Nacional, vol. LX, 1940.

Com o nome de Maria Callcott:

1. A Short History of Spain, Murray, Londres, 1828. 
2. Letter to the President and Members of the Geological Society in Answer to Certains Observations Contained in Mr. Greenough's Anniversary Address of 1834, Brettall, Londres, 1834.

3. Description of the Chapel of the Annunziata dell Arena in Padua, with Engravings from Drawings by A. W. Callcott, R. A. Brettall, Londres, 1835.

4. Little Arthur's History of England, Murray ${ }^{4}$, Londres, 1835.

5. Essays towards the History of Painting. E. Moxon, Londres, 1836.

6. Continuation of Essays towards the History of Painting. E. Moxon, Londres, 1838.

7. The Seven Ages of Shakespeare. An Essay by Lady Callcott, 1840.

8. The Little Brackenburners and Little Mary's Four Saturdays, Londres, 1841.

9. A Scripture Herbal, Longman, Londres, 1842.

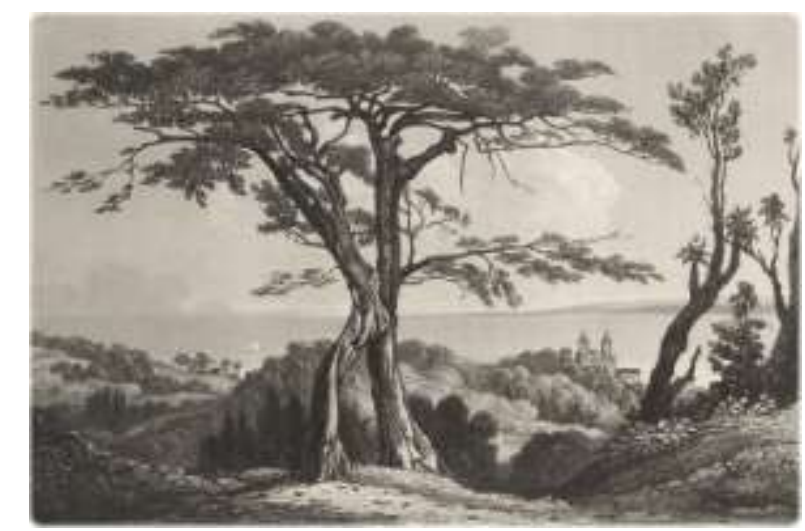

Maria Graham, Bahia, Journal of a voyage to Brazil, and residence there, during part of the years 1821, 1822, $\underline{1823}(1824)$

Sob desígnios recorrentes o fim e o início do mundo exercem idênticos fascínios. Chegam a confundir-se e interrompem a diferenciação lógica entre o que seja/é um [o] início e aquilo que seja/é um [o] fim. O fim pode estar tão próximo da consciência de seu princípio que o paradoxo se converte em algo justificável como se o brotar de uma planta estivesse - automaticamente - na ordem de seu termo, como se houvesse uma fusão de vida-morte, como ensinou Clarice Lispector, pois que interrompendo a quietude e a condescendência para se autorizar a fruir a vida em viagem intrépida e convicta.

Trazer o fim do mundo até se aconchegar por perto, nas fronteiras entre a sedução e o conforto que as ideias possam proporcionar: através da escrita e do desenho, Maria Graham apropriou-se do que viu, experienciou, ouviu, tocou, lhe 
sussurraram quer as paisagens estranhas, quer as pessoas acalentadas por destinos incertos.

Criar um herbário, uma espécie de jardim onde as plantas se desenham e descrevem, é contrariar a morte e menosprezar a distância exótica onde essas fragilidades se localizam. Transporta-se o que esteja no fim do mundo até nós.

Uma vez que estivemos no Instituto de Literatura Comparada Margarida Losa, não deixaria escapar a oportunidade de tomar por companhia alguns excertos literários (e não somente estéticos e/ou da filosofia - se é possível dividirmos assim, tão basicamente, as águas... não estagnadas mas em movimento... Gaston Bachelard dixit...). Assumir algumas afinidades eletivas, perante vós, sabendo que elas alavancam o presente estudo. O fato de este Seminário permanente ser "Do fim do mundo" determinou, obviamente, quais os títulos e os autores escolhidos. E atendendo a que se trata da Série VI, por certo recuperei as (minhas) reminiscências pitagóricas...

\section{Bibliografia}

Andrade, Carlos Drummond de (2001), Antologia Poética, Lisboa, Dom Quixote. Andresen, Sophia de Mello Breyner (1976), Livro Sexto, Lisboa, Moraes.

Antunes, Arnaldo (2006), Antologia, Vila Nova de Famalicão, Quasi.

Barros, Manoel de (1994), o Livro das Ignorãnças, Civilização Brasileira.

Bessa-Luís, Agustina (2009), Embaixada a Calígula, Porto, Guimarães Editores. 
Bourguinat, Nicolas (2008), "Voyage et genre, une interrogation renouvelée", in Le Voyage au féminin - perspectives historiques et littéraires (XVIIIe - XXe siècles), Estrasburgo, Presses Universitaires de Strasbourg.

Brilli, Attilio (1995), Quando Viaggiare Era un'Arte. Il romanzo del Grand Tour, Bolonha, Il Molino.

Butler, Samuel (1872), Everwhon or Over the Range, www.booksshouldbefree.com/ download/text/Erewhon-by-Samuel-Butler.txt

Cendrars, Blaise (2005), Poesia em Viagem, Lisboa, Assírio \& Alvim.

Egéria (2017), Uma Narrativa de Viagem aos Lugares Santos, Uberlândia, EDUFUUniversidade Federal de Uberlândia.

Goethe, J. W. (1786), Italienische Reise, www.goethezeitportal.de/wissen/projektepool/ goethe-italien/rom/rom-in-alten-ansichten/rom-egeria.html

Hatherly, Ana (2003), O Pavão Negro, Lisboa, Assírio \& Alvim.

Helder, Herberto (2014), Poemas Completos, Lisboa, Assírio \& Alvim.

Lacarrière, Jacques (1997), "Voyageurs, voyageants et voyagés", Le Monde de l'Éducation, de la Culture et de la Formation, no 248.

Lambert, Madame la Marquise de (1748), CEuvres de Madame la Marquise de Lambert. Rassemblées pour la première fois. On y a joint diverses pièces qui n'ont point encore paru. Avec un abregé de sa vie, Lausanne, Marc-Michel Bousojet \& Compagnie.

Lapierre, Alexandra, \& Mouchard, Christel (2015), Elles Ont Conquis le Monde - Les grandes aventurières 1850-1950, Paris, Artaud.

Le Livre de la Révelation (s/d), file:///K:/A - A SITE/APOCAL/ApoIntro.html (consulta em fevereiro de 2019).

Lispector, Clarice (2002), A Hora da Estrela, Lisboa, Relógio d’Água.

-- (2004), Aprendendo a Viver (Crônicas), Rio de Janeiro, Rocco.

Maffesoli, Michel (2001), Sobre o Nomadismo, Rio de Janeiro, Record. 
Monicat, Bénédicte (1996), Itinéraires de l'Écriture au Féminin: voyageuses du 19e siècle, https://books.google.pt/books?id=SvtikX04DdcC\&pg=PA78\&lpg=PA78\&dq=benedicte+ monicat+itin\%C3\%A9raire+de+l\%27ecriture+au+feminin\&source=bl\&ots=KcH2OIXIOg \&sig=IvLE2BLgzCCM1ZvqUOgagsQr5ao\&hl=pt-

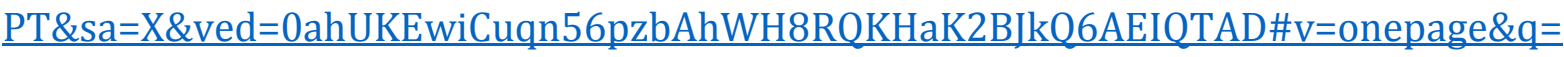
benedicte\%20monicat\%20itin\%C3\%A9raire\%20de\%20l'ecriture\%20au\%20feminin\&f =false

Murray II, John - Archive online (1778-1843) in https://digital.nls.uk/jma/who/johnmurray-ii/index.html

Nietzsche, Friedrich (1902), Le Voyageur et son Ombre - Opinions et sentences mêlées (Humain, trop humain, $2^{e}$ partie), Paris, Mercure de France.

Pereira, Ligià Fonseca (1990), “Itineraire d'une voyageuse en Europe: Nísia Floresta (1810-1885)", Cahiers du Brésil Contemporain, n 12.

Pina, Manuel António (2012), Poesia Reunida, Lisboa, Assírio \& Alvim.

Pomeroy, Jordana (2005), Intrepid Women - Victorian Artists Travel, Cornall, Ashgate.

Quignard, Pascal (1999), Vida Secreta, Lisboa, Ed. Notícias.

Rilke, Rainer Maria (1983), Poemas - As Elegias de Duíno e Sonetos a Orfeu, Lisboa, Oiro do Dia.

Rogers, Rebecca \& Thebaud, Françoise (2008), Voyageuses, https://journals.openedition.org/clio/7553

Rogers, Rebecca (2008), "Décrypter le regard national: voyageuses anglaises et françaises en Algérie au XIX ${ }^{\mathrm{e}}$ siècle", Le Voyage au Féminin - perspectives historiques et littéraires (XVIIIe - XX siècles), Estrasburgo, Presses Universitaires de Strasbourg.

Rousseau, Jean-Jacques (1754), Discours sur l'Origine de l'Inégalité, https://philosophie.cegeptr.qc.ca/wp-content/documents/Discours-surlin\%C3\%A9galit\%C3\%A9-1754.pdf

Sena, Jorge de (1989), Visão Perpétua, Lisboa, Edições 70. 
Starobinski, Jean (1994), L'Invention de la Liberté, Paris, Skira.

Sontag, Susan (1997), O Amante do Vulcão, Lisboa, Quetzal.

Todd, Janet (2000), The Secret Life of Aphra Behn, Londres, Pandora.

Venayre, Sylvie (2012), Panorama du Voyage - 1780-1920 - Mots, figures, pratiques, Paris, Les Belles Lettres.

Maria de Fátima Lambert é Licenciada em Filosofia; Mestre e Doutora em Filosofia Moderna e Contemporânea - Estética pela Faculdade de Filosofia de Braga/ Universidade Católica Portuguesa. Professora Coordenadora em Estética e Educação Escola Superior Educação/ Politécnico do Porto; Professora Convidada em Universidades do Brasil, Itália e Espanha. Bolseira FCT no projeto "Writing and Seeing" 2000 e 2004. Diretora (2014-2016) e Membro Integrado InED (Centro de Investigação e Inovação em Educação, ESE/P.Porto), onde coordena vários projetos, destacando-se: “A [in]visibilidade da Mulher na História da Arte e do Pensamento"; "Educação Estética e formação do público da Arte Contemporânea" que integra programa de curadorias em Casas-Museu em Portugal, Espanha e Brasil. Membro de várias Comissões Científicas. Desde 1989 desenvolve atividade como Crítica de Arte (AICA), Programadora e Curadora Independente de exposições e residências artísticas, privilegiando o eixo Portugal-Brasil. Bailarina na Companhia da Academia de Bailado Pirmin Trecu até 1989. Conferencista e autora de vários livros, textos, artigos e comunicações publicados. 


\section{NOTAS}

${ }^{1}$ Na Filosofia assim como na Poesia a imagem da viagem serve propósitos incontornáveis, estimulando a lucidez de saberes vivenciados e refletidos sob metáforas, símbolos e alegorias subsumidas, imagens obsessivas, recuperando o termo de Charles Mauron. O Itinerário da Mente para Deus de São Boaventura (séc. XIII) referencia uma ideia de jornada que se diferencia de A Subida ao Monte Ventoux de Petrarca (1336), pequeno livro emblemático que, ainda que orientado ao termo simbólico da ascensão, subsiste através das conivências reais, experimentadas pelo esforço físico na caminhada.

2 Cf. https://sonofthefathers.wordpress.com/2010/10/27/peregrinatio-egeriae/ (consulta em maio de 2018).

3 Destaque-se o livro editado por Jordana Pomeroy, Intrepid Women - Victorian Artists Travel, Cornall, Ashgate, 2005. A publicação surgiu na sequência da exposição assim designada, que se realizou no National Museum of Women in Art, de Washington, em 2002. Jordana Pomerey foi responsável, com

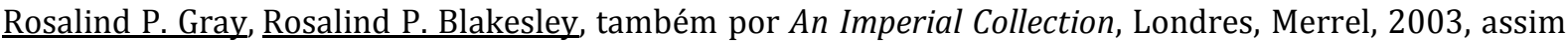
como de Royalists to Romantics: Women Artists from the Louvre, Versailles, and Other French National Collections, Londres, Scala Arts Publishers, 2012, entre outras edições.

${ }^{4}$ Cf. Arquivo de John Murray in https://digital.nls.uk/jma/who/john-murray-ii/index.html 



\section{Libretos}

\section{Dentro da boca é escuro. Sobre poesia e o fim do mundo}

\section{Patrícia Lino}

UCLA (University of California, Los Angeles)

Resumo: A palavra poética, como matéria plástica multidisciplinar, manifestação e experiência, põe em causa a estrutura normativa do cânone ocidental. Exige, além disso, ao(à) crítico(a) literário que se reeduque, continuamente, a partir da leitura empática do texto do Outro.

Palavras-chave: poesia, performance, oralidade, cânone

Abstract: The plasticity and multidisciplinary nature of the poetic word, as manifestation and experience, challenges the normative structure of the Western canon. In addition to that, it demands a continuous reeducation of the literary critic through the empathetic reading of the textual Other.

Keywords: poetry, performance, orality, canon

\section{A}

Todos os humanos participam de conhecer-se a si mesmos e ser sábios.

Heraclito (B116) 


\section{Um clarão luminoso.}

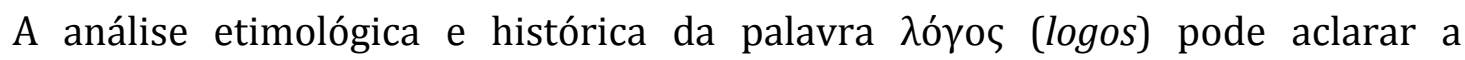
expressão aparentemente paradoxal "lógica poética", porque $\lambda$ ó ${ }^{\circ}$ significa "fábula" antes de querer dizer "discurso". A sua dimensão fantástica liga-se, assim, a outra palavra grega, $\mu \tilde{0} \theta$ os, o mito ou a ação mental que existe no silêncio e precede o "falar natural" (um conjunto de gestos que tinham relação direta com o ritmo ${ }^{1}$ e as ideias). $\mathrm{Ou}$ o lugar da comunicação poética "e a sua tendência ou sua aptidão para gerar mais prazer do que informação" (Zumthor 2007: 64) que nos recorda, além da indispensabilidade da voz (que estaria na base da transmissão da palavra viva), a importância dos ouvidos e dos olhos, centrais para o processo de assimilação do prazer, e da memória; que, no contexto desta situação oral, diria respeito à conservação e recriação do prazer.

Existe, assim, uma diferença estrutural entre o processo de transmitir a palavra poética viva, que une de modo orgânico ideias, gesto, voz, olhos, ouvidos, emoção e memória, e o processo de transmissão da palavra poética escrita. 0 segundo, que é artificial e se afasta estruturalmente do corpo uno, aproxima-se dele, muito pontualmente, através da leitura. A espontaneidade do ato de ler com a voz a palavra poética escrita corresponde ao desejo de repor a unidade perdida. Ainda assim, a tentativa, condenada a ser para sempre incompleta, não se dissocia do prazer.

Antes de poder descrever o começo do mundo, a poesia é, como um clarão luminoso, o seu fim, e, ao mesmo tempo, a pluralidade do(s) começo(s) que advém do fim.

Consecutivamente.

\section{0 perigo da poesia.}

República, Livro X. O alvo de Platão é, mais do que a poesia como fenómeno estrutural e estruturado, o resultado psicológico ou emocional da experiência poética. E a questão, lida e interpretada de tantas formas válidas e erróneas ao longo dos tempos parece residir aqui: a poesia, como estrutura ou resultado, não ocupa um lugar inferior ao lugar da filosofia. 
A poesia é suficientemente poderosa para que Platão denuncie o seu perigo. Um veneno psíquico. Mais: questionar a validade do uso social da poesia implica, para Platão, questionar o ato de memorizar e dizer ou performar em público.

Mas a denúncia tropeça na contradição quando, ao dispensar o fazer poético, Platão planeia a narração social das histórias recorrendo dissimuladamente ao poema ou às estratégias narrativas do mito. Platão conhece o poder da palavra metafórica e confia nela a ponto de colocar em risco, por nunca esclarecer o que há de comum entre a poesia e a filosofia ou a filosofia e as outras artes, o seu projeto filosófico.

\section{Poesia, s.f.: Pharmakós nocivo milenar.}

As passagens, estórias ou anedotas ocidentais, também elas parte da tradição literária europeia, sobre a recepção emocional ou patética da poesia, ou sobre o poder da palavra poética, são várias e tão sugestivas quanto antigas.

A primeira delas pode ler-se no canto VIII da Odisseia, quando Ulisses chora ao escutar as palavras de Demódoco, e cobre, envergonhado, a cabeça (vv. 83-85). Apesar de reconhecer o talento do aedo, Ulisses repreende o perigo das palavras de Demódoco, que lhe encolerizam ( $\theta u \mu$ òv) o coração (vv. 178-179).

Outra delas será, certamente, a que Suetónio ou Sérvio Honorato registaram sobre Otávia, irmã de Augusto, e o canto VI da Eneida de Virgílio. Contam ambos que, depois de ouvir a referência ao falecido filho Marcelo, Otávia desmaiou ou esteve perto de desmaiar².

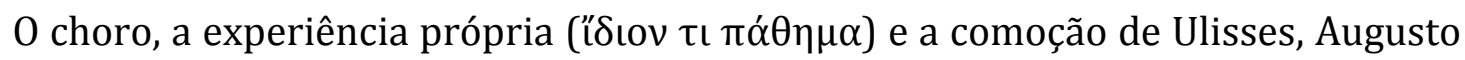
ou Otávia, provocados pela performance da palavra poética, abalam, suspiro a suspiro contra a instrumentalização da linguagem, os pilares da ordem. Compõem-se, além do mais, coletivamente ${ }^{3}$. 0 mundo regrado acaba na respiração rítmica da palavra poética e recomeça, logo depois, como perda e memória.

À semelhança das lágrimas, o riso (e a paródia, a sátira, a ironia ou a metapoesia) aproximam-se, como nos lembra Bergson, da inteligência pura, que contraria a mecanização da vida, adormenta momentaneamente o coração e regulamenta, num movimento inverso, a sociedade. 


\section{Não sei se a salvação existe, mas existe - certamente - a tentativa de nos salvarmos.}

Ao mesmo tempo, a palavra poética evita, como forma de honrar os heróis, um

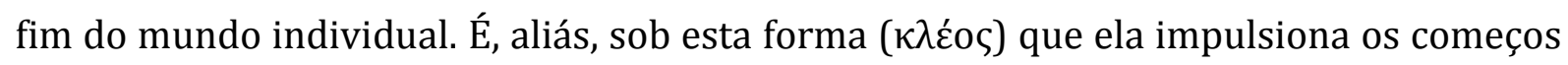
do primeiro dos poemas ocidentais. A narração da Ilíada depende, no canto I, de um dos dois destinos que Tétis prevê para Aquiles (vv. 413-418). Lutar, morrer em Tróia e ser cantado eternamente pelos poetas.

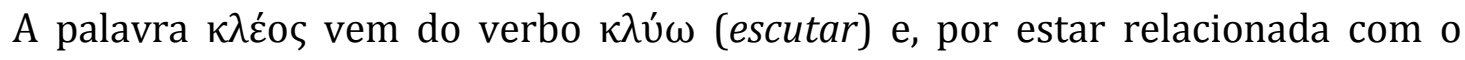
canto dos poetas, que escutam o sopro celebrador das Musas sobre os heróis, significa fama, glória ou reputação. A fama estende-se automaticamente ao estatuto dos poetas.

A memória, memorização e a oralidade da palavra poética também se opõem, como formas de sobrevivência, a um fim do mundo imposto e material. Há, com efeito, algo similar entre um dos últimos gestos de Boris Pasternak (Kayzer 2000) e a obediência cega de Ezequiel (Ez 2:9 - 3:2). 0 primeiro, na história contada por George Steiner a Wim Kayzer ${ }^{4}$, incentiva, correndo o risco de morrer, uma multidão de duas mil pessoas a dizerem o soneto 30 de Shakespeare (que ele próprio havia traduzido); e ao segundo Deus ordena que coma a mensagem escrita que lhe tinha entregado antes. A comoção da palavra reverberada, que, num contexto opressor, passa de Pasternak para os(as) outros(as), escapa ao controlo do poder, fortalece-se a partir da ingestão, literal (como no caso de Ezequiel) ou intelectual. Perpetua-se contra o risco e a dominação. É original, plena, incontrolável.

\section{B}

Se você tem uma ideia incrivel é melhor fazer uma canção Está provado que só é possível filosofar em alemão

Caetano Veloso 


\section{Cânone: salvação ou privilégio?}

A palavra literatura, do latim littera (letra), litteratura, acompanha o nascimento da ideia das nações e da identidade nacional. Trata-se de um projeto exclusivamente europeu. A ideia, em si, não vem designar nada novo, mas inicia, a nível disciplinar, a necessidade correspondente: literatura já não designará mais todos os textos que transmitem o conhecimento, mas apenas uma pequena parte deles. Essa pequena parte, que passará, dois séculos depois, a ser a literária, nomeia certos géneros literários específicos, unidos por uma ideia estética, e serve, ao mesmo tempo e muitas vezes, os discursos nacionais e nacionalistas da segunda metade do século XVIII.

Apesar de a dimensão nacional ou identitária do termo literatura designar um objeto que não segue, na maior parte do tempo, um propósito nacionalista ou político, o termo aparece, desde do início, ligado à ideia de identidade nacional. As denominações ("literatura portuguesa", "literatura brasileira") formam-se a partir da geografia e da língua. Esta última, que pode ser partilhada em mais de dois lugares, no caso particular dos países que colonizaram e foram colonizados, é o instrumento de imposição da identidade de uns e, com frequência, o instrumento de resistência dos segundos.

Os termos lusófono, hispânico ou anglo-saxónico não aclaram os conflitos, dilemas e consequências pós-coloniais. Tampouco antecipam a diversidade de posições ou reações políticas e literárias perante ou a partir de uma língua imposta.

A língua, que traz com ela um conjunto vasto e vago de expressões, designa as manifestações culturais de uma ou mais áreas geográficas. Por uma questão de organização, controlo político ou por assentar no sentimento de pertença que os(as) integrantes de uma determinada comunidade ou grupo social têm ao fazer parte de uma mesma "comunidade imaginária"5, um número ínfimo destas manifestações culturais transforma-se em estereótipo. 0 estereótipo nacional ou nacionalista impõe-se, entre outros fenómenos, sobre a própria língua.

A literatura pode ou não partir desse estereótipo. Se parte dele, a grande literatura fá-lo unicamente com o propósito de desconstruí-lo e destruí-lo.

Se a cada cultura corresponde um conjunto de estereótipos, a esse mesmo conjunto de estereótipos terá de corresponder um conjunto de regras ou preferências. Ou o fim de muitos mundos como forma de preservar um só. 
O cânone nacional literário ou o cânone ocidental são construídos com base, entre outros pontos, nesse conjunto de regras.

O cânone antecede, como termo e coisa, o termo literatura e apoia-se, como o estereótipo, na facilidade que há em categorizar e nas vantagens trazidas pela

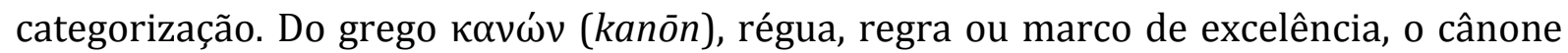
estabelece-se como princípio normativo com os filósofos alexandrinos, remodela-se na Idade Média, volta a transformar-se com os renascentistas e encaixa, porque exclui mais do que inclui, nos discursos nacionalistas e heroicos modernos do séc. XIX.

Como o estereótipo, o cânone, hegemónico e homogéneo, altera-se e traz com ele esta pergunta, não tão original mas continuamente urgente: quem faz o cânone? Ou, quem precisa dele? E o cânone ocidental-masculino-imperialista cresce a partir deste pressuposto narcisístico: entram no cânone aqueles, aquelas e aquilo que pode ser identificado e sobretudo compreendido por quem faz o cânone. Equivale, por outras palavras, à institucionalização da literatura

como instrumento pedagógico de viabilização da nossa diferença cultural em razão de sua força simbólica para sustentar a coerência e a unidade política da concepção romântica da nação como "o todos em um". (Schmidt 2000: 84)

Interminável, a lista assenta, além disso, na lógica colonial: Aquiles ou o que queremos de Aquiles entram no cânone, mas Aquiles não é europeu (Mignolo 1995). Apesar de serem aclamados pela crítica literária luso-brasileira, Machado de Assis entra no cânone universal quando Harold Bloom o reconhece cem anos depois (Rohter 2000), Eça de Queirós e Fernando Pessoa idem, e Clarice Lispector ganha popularidade fora do Brasil ao receber a atenção do jornalismo norte-americano.

A fragilidade do cânone literário assenta, assim, na natureza da sua formação, tautológica e irónica: o cânone reconfigura-se a partir das suas próprias limitações e, porque parte de princípios estrategicamente políticos, que são tão voláteis quanto o próprio cânone, existe para desdizer-se.

Os pilares canónicos definem um mundo muito particular, e algo provinciano, com base no fim de muitos outros mundos ou galáxias. E a pergunta impõe-se: se o mundo acabasse hoje, que narrativa do mundo realmente acabaria? 


\section{0 cânone acidental.}

A propósito da literatura das minorias, resultado da expansão e sistematização das lutas sociais, o raciocínio desdobra-se e obriga-nos a retroceder até às palavras de Fokkema e Ibsch que, em 2000, antecipavam um ajuste entre cânone e "contracânone". 0 ajuste, escreveram eles, surgiria da diferença óbvia entre o conhecimento transmitido pelo cânone e o conhecimento transmitido pelas margens ou textos não canonizados. Parece-me que a diferença não diz respeito apenas ao que é diferente entre um e outro mundos, mas à destruição de um modelo aristotélico e cartesiano binário ou da lógica excludente metafísica ocidental, que não representa nem procura representar a multiplicidade das expressões humanas e culturais. E por ser justamente parte da superação de um pensamento alternativamente exclusivo, o ajuste complica-se.

1. Não podemos questionar a urgência da luta pelos direitos das mulheres, dos(as) negros(as), gays e lésbicas, transgénero, intersexuais ou da comunidade indígena.

2. A luta pelos direitos destas comunidades deve, no contexto literário, corresponder à sua integração autoral no cânone literário. Quer dizer: um cânone onde eles e elas são autores(as).

3. A integração autoral destas comunidades no cânone literário não deve, contudo, basear-se unicamente no que define a comunidade: ser mulher ou ser indígena. Pode ou deve, portanto, basear-se nas mesmas exigências e juízos de valor com que encaramos o trabalho de um autor europeu branco?

4. Por outro lado, a compensação errónea dos direitos das minorias não deveria conduzir à destruição de conceitos como a influência ou a imitação, que foram e são centrais para entender, por exemplo, a literatura dos países colonizados. Isto é, a interpretação extrema ou extremista de teóricos como Homi Bhabha não deveria desembocar na anulação dos modelos do tempo (não há antes nem depois) e da qualidade (não há melhor nem pior).

A questão é, no entanto, bastante mais complicada. 


\section{Primeiro paradoxo.}

A literatura parece ter, então, de politizar-se.

Ao mesmo tempo, a literatura não tem que, sobretudo porque os atos de criar e pensar são irreversivelmente duas formas de resistência. Por extensão, a crítica literária parece ter de politizar toda a literatura sem lê-la ou entendê-la ${ }^{6}$, quando o seu propósito deveria ser, modestamente, oferecer sugestões de leitura inclusivas e, menos modestamente, modelar o cânone (de modo rigoroso e inclusivo).

\section{Segundo paradoxo.}

Claro está que os conceitos que usamos ("grande literatura", "tempo" ou "qualidade"), bem como os instrumentos de que nos servimos para ler qualquer texto literário, são resultado do cânone crítico e da bibliografia ocidentais. Por isso, mais do que incluir e analisar as minorias por elas serem minorias, temos em mãos o dever de questionar e reconfigurar os conceitos e instrumentos referidos a partir da leitura e análise de todos e todas.

\section{Terceiro paradoxo.}

O cânone ocidental é exclusivamente logocêntrico e muitas das expressões literárias ignoradas pelo cânone são averbais.

\section{Quarto paradoxo.}

Os últimos três paradoxos assentam na ideia de que as minorias querem fazer parte do cânone ocidental. Talvez não queiram.

\section{C}

Esqueça a caneta, escreva de lápis

Quando a maré mudar, você passa a borracha

Porque a vida do povo é assim,

às vezes tá tranquila e às vezes 'tá ruim.

Cidinho e Doca 


\section{Outro clarão luminoso.}

A tradição interdisciplinar da poesia brasileira tem mais de um século e está intimamente ligada ao domínio público. São, de facto, vários(as) os(as) poetas brasileiros(as) que nos lembram, conscientemente ou não, da acepção original do termo publicar que, antes de fazer referência ao registo escrito, diz respeito à exposição pública das ideias e do corpo, e do corpo íntimo (publicare está na raiz da palavra portuguesa púbico).

A expressão poética interdisciplinar parece manifestar-se em duas frentes. Por um lado, os movimentos poéticos brasileiros que exploraram a relação da poesia com as outras artes, desde da primeira fase do modernismo até às gerações da Poesia Concreta, Neoconcretismo e Poema/processo, abriram inquestionavelmente as portas para que, dos anos 70 até aos dias de hoje, o(a) poeta se reinvente a partir da matéria. Entre os(as) autores(as) mais recentes, destaco os trabalhos multidisciplinares de Arnaldo Antunes, André Vallias, Ricardo Aleixo, Miró da Muribeca, Guilherme Gontijo Flores, Ricardo Domeneck, Dimitri BR, Angélica Freitas, Reuben, Heyk Pimenta, Luca Argel ou Júlia de Carvalho Hansen que colaborou em Janeiro de 2020 com a banda E A Terra Nunca me Pareceu Tão Distante (TTNG).

A exposição pública das ideias e do corpo traz, além disso, a possibilidade de estudar e recriar infinitamente a matéria do poema e repensar o corpo como um aparelho tecnológico. Há nela a necessidade de caminhar para trás, no sentido da perda, da primeira das vozes, do mais antigo dos sons.

Por outro lado, e sem aparente ligação com os fenómenos poéticos interdisciplinares acima mencionados, a poesia das favelas, que acontece sobretudo no Rio de Janeiro, destaca-se por ser exclusivamente oral e performática. Mais: a palavra da poesia das favelas não se edita ${ }^{7}$. Existe dentro da performance e materializa-se no vídeo $^{8}$. Põe também em causa os instrumentos convencionais da crítica: a análise, tal como a conhecemos, o ensaio, tal como o pensamos, a aula de poesia, tal como a imaginamos, ou a antologia, que perdeu, num oceano agitado de publicações e novidades, a sua função modeladora e organizadora9 ${ }^{9}$ Recupera, além disso, pela capacidade que o som tem em infiltrar-se e viajar, a sua função original 
desestabilizadora e é, em si, uma experiência própria que apela diretamente à experiência própria do Outro.

A dinâmica da poesia das favelas tem, de resto, algo de tão de antigo como moderno, porque adapta logicamente a estrutura da slam poetry, do rap e do funk ${ }^{10}$ a partir da desconstrução das normas linguísticas do português. A palavra falada, que estremece num vibrato ininterrupto através dos movimentos do corpo, anuncia o fim do mundo do cânone ocidental, porque, para o(a) poeta da favela que não pôde ir à escola, o cânone ocidental não existe e, se existe, não o(a) inclui.

0 que fazer criticamente perante o fim do nosso mundo, do corpo desajustado que diz e dos movimentos de um corpo desajustado que, aos olhos do Estado, não existe? Qual é exatamente a diferença entre este corpo e a multidão que recita Shakespeare? Qual é o lugar deste corpo vivo, mas inexistente, que faz tremer o cânone, a nação, a polícia, o arquivo, o documento, a antologia, a lição de métrica, Deus, a ciência e o(a) poeta não-favelado(a) que escreveu sobre as favelas? E a mim, que tento entendê-lo?

\section{0 que há depois do fim do mundo?}

Não há mérito algum no esforço que faço para entendê-lo. De facto, a educação do(a) crítico(a), que trabalha diariamente com a palavra, deveria ser, além de multidisciplinar, empática e humilde. Deveria, também, renovar-se permanentemente; entender que, como a poesia acompanha o mundo, a crítica deveria acompanhar o movimento tecnológico da poesia.

Além disso, o poder e a ancestralidade do grito rítmico das favelas ou do(a) poeta que se reinventa a partir da palavra poética viva não anulam a validade dos Idílios de Teócrito, Shakespeare ou Camões. Complementam-nos e complementam-se. Dizem-nos muito, aliás, sobre o poder plástico da palavra que se rebela e reaparece, continuamente, sob variadíssimas formas. Ela existe, em si e para si, independentemente de qualquer estrutura normativa, como um espaço de potência. 


\section{Bibliovideografia}

Badhe, Yaamir (2020), "Classics Faculty proposes removal of Homer and Virgil from mods syllabus", The Oxford Student, 17 de Fevereiro.

Diplo (2008), Favela on Blast, disponível em https://bit.ly/2Td3MIj.

Fokkema, Douwe Wessel, \& Ibsch, Elrud (2000), Knowledge and Commitment. A problemoriented approach to literary studies, John Benjamin Publishing Company.

Kayzer, Wim (2000), Of Beauty and Consolation, disponível em https://bit.ly/383nqM7.

Manguel, Alberto (2014), A History of Reading, Nova Iorque: Penguin Books [1996].

Mignolo, Walter (1995), The Darker Side of the Renaissance, University of Michigan.

Paz, Octavio (1972), Signos em Rotação, trad. Sebastião Uchoa Leite, São Paulo: Perspectiva.

Perloff, Marjorie (1996), "Whose new American poetry?: Anthologizing in the nineties", Diacritics, Johns Hopkins University Press, vol. 26, no 3/ 4, Fall-Winter, 104-123.

Rohter, Larry (2008), "After a century, a literary reputation finally blooms", The New York Times, 12 de Setembro.

Schmidt, Rita (2000), "Mulheres reescrevendo a nação”, Revista de Estudos Feministas, Universidade Federal de Santa Catarina, vol. 8, nํ. 1.

Servius (1471). In tria Virgilii Opera Expositio.

Waldman, Katy (2018). "Reading Ovid in the age of \#Metoo", The New Yorker, 12 de Fevereiro.

Zumthor, Paul (2014), Performance, Recepção, Leitura, trad. Jerusa Pires Ferreira e Suely Fenerich, Cosac Naify. 
Patrícia Lino (Portugal, 1990) é professora universitária e poeta. Ensina literaturas e cinema luso-brasileiros na UCLA (University of California, Los Angeles). É a autora de Antilógica (2018) e Manoel de Barros e A Poesia Cínica (2019). Dirigiu Vibrant Hands (EUA, 2019) e Anticorpo. Uma Paródia do Império Risível (EUA, 2019). Publicou, apresentou e expôs ensaios, poemas e ilustrações em mais de seis países. A sua investigação centra-se, neste momento, na poesia contemporânea, culturas visual e audiovisual, paródia e anticolonialismo, intermedialidade e cinema luso-brasileiro. É editora da revista de poesia e crítica Virada. http://patricialino.com.

\section{NOTAS}

1 "Em certo sentido pode-se dizer que a linguagem nasce do ritmo ou, pelo menos, que todo ritmo implica ou prefigura uma linguagem. Assim, todas as expressões verbais são ritmo, sem exclusão das formas mais abstratas ou didáticas da prosa. [...] 0 ritmo é condição do poema, enquanto é inessencial para a prosa" (Paz 1972: 11-12).

2 "et constat hunc librum tanta pronuntiatione Augusto et Octaviae esse recitatum, ut fletu nimio imperarent silentium, nisi Vergilius finem esse dixisset" (Servius 1471: 861; "E consta que esse livro [canto VI da Eneida] tenha sido recitado a Augusto e Otávia tão expressivamente que ao choro copioso eles imporiam o silêncio, não fosse Virgílio ter dito que era o fim").

${ }^{3}$ Ao contrário do que diz Alberto Manguel sobre a leitura em voz alta, a força e graça destas passagens reside no facto de o conteúdo do que se lê não ser de todo previsível para quem escuta. "Reading out loud is not a private act, the choice of reading material must be socially acceptable to both the reader and the audience" (Manguel 2014: 122).

${ }^{4}$ Transcrevo as palavras de George Steiner: "On the third day his friends said, 'look, they are going to arrest you anyway, maybe you should say something for the rest of us to carry with us.' He was well over six feet, incredibly beautiful, and when Pasternak got up, everyone knew. You could hear the silence across Russia. And he gives a number. It was the number of a certain Shakespeare sonnet - of which Pasternak had done a translation which the Russians say, with Pushkin, is one of their greatest texts. Sonnet 30. They say the 
Russian translation is as beautiful. 'When to the sweet session of silent thought / I summon up remembrance of things past.' And the two thousand people stood up, and they recited it by heart - the Pasternak translation. It said everything. It said: you can't touch us; You can't destroy Shakespeare; You can't destroy the Russian language; You can't destroy the fact that we know by heart what Pasternak has given us. And they didn't arrest him. Well, even if the sons of bitches do arrest you - it's too late. The people already have your treasure with them" (Kayzer 2000).

${ }^{5}$ Expressão de Bennedict Anderson, Imagined Communities, 1983.

${ }^{6}$ Por um lado, há, com efeito, leituras ou interpretações desajustadas (como as há, de resto, a nível teórico ou filosófico) que tendem a reduzir o valor literário da obra ao seu projeto político ou social - dizer o que o(a) autor(a) efetivamente não disse. Por outro lado, existem modelos interpretativos, especialmente no que diz respeito aos clássicos ou textos canónicos, que insistem em ignorar a abordagem de temas como a violência de género. Exemplo: o debate sobre a abordagem convencional ou honesta (uma e outra não parecem coincidir) de certas passagens das Metamorfoses de Ovídio é recente. Reconhecer que tais passagens são, na verdade, a descrição da violação sistemática do corpo da mulher anula a importância da obra (Waldman 2018)? De um modo ou de outro, parece-me que a dificuldade do debate passa por encontrar um ponto intermédio entre qualidade, valor histórico e/ou literário e direitos humanos. Remover, por exemplo, Homero e Virgílio dos curricula é tão trágico quanto ineficiente. A remoção de ambos não acabará com a desigualdade de género (Badhe 2020).

${ }^{7}$ Não ignoro, claro está, a importância das instituições e dos festivais que se formaram a partir da difusão da poesia feita nas favelas, como a FLUP ou o Slam Brasil. Interessa-me, porém, a palavra que vibra, intocada e resistente, ainda longe do olhar editorial.

${ }^{8}$ Aconselho, a este propósito, dois canais Youtube: MargiNow e Grito Filmes.

${ }^{9}$ Questão, de resto, introduzida e discutida por Marjorie Perloff (1996).

${ }^{10} 0$ samba parece não fazer parte da lista. Cf. Favela On Blast, documentário gravado na Rocinha em 2008. 



\section{Libretos}

\section{Saldo e ocultação dos Seminários do Fim do Mundo}

\section{Pedro Eiras}

Universidade do Porto - ILC

Resumo: Breve texto de «saldo» e «ocultação» dos Seminários do Fim do Mundo, apresentado na sua última sessão (série VI, seminário no 4, a 13 de Dezembro de 2018). Panorâmica dos trabalhos realizados e das principais linhas de pesquisa desenvolvidas.

Palavras-chave: Seminários do Fim do Mundo, saldo, ocultação

Abstract: Brief «balance» and «occultation» of the End of the World Seminars, presented at its last session (series VI, seminar 4, on the 13th december 2018). Overview of the work carried out and of the main lines of research developed.

Keywords: End of the World Seminars, balance, occultation 
Não, o mundo não acabou no dia 21 de Dezembro de 2012, suposto fim anunciado por duas estelas maias, e por todo o planeta temido e festejado - pretexto para jantares, bebidas, viagens, packs turísticos, programas especiais em hotéis. Nem no dia 22 de Fevereiro de 2014, data do Ragnarök, ou crepúsculo dos deuses para os antigos viquingues. Nem sequer nos dias 22 a 28 de Setembro de 2015, em que a Terra deveria ter sido atingida, segundo alguns visionários, por uma imenso cometa. Nem no dia 23 de Setembro de 2017, quando teríamos colidido com o muito célebre Nibiru, ou Planeta $\mathrm{X}$, frequentemente anunciado e outras tantas vezes adiado para nova oportunidade. Nem no dia 19 de Novembro do mesmo ano, segundo novos cálculos e obscuras decifrações de alguns versículos bíblicos, com destaque para excertos do Apocalipse. De facto, o mundo ainda não acabou, mas o fim pode estar próximo - em 2036 o asteróide Apophis talvez colida com a Terra, e o Livro de Daniel anuncia o fim do planeta para 2060, Isaac Newton dixit.

Seja como for, enquanto as várias profecias foram falhando e outras novas as iam substituindo, tivemos oportunidade de estudar a representação e o imaginário do fim nos Seminários do Fim do Mundo. Entre 2013 e 2018, o Instituto de Literatura Comparada Margarida Losa organizou 24 seminários, sempre seguidos de debates. Entretanto, foram também publicados 11 libretos on-line: Materiais para o Fim do Mundo nos 1 a 11, recolhendo as comunicações dos seminários e textos afins; foi publicado ainda um libreto extra-série, com o argumento do documentário Dia 32, de André Valentim Almeida, em parte inspirado pelos próprios seminários. Em 2015, a revista eLyra dedicou também um número ao tema Poesia e Fim do Mundo, que co-organizei com Paulo de Medeiros.

No fim destes seis anos de debate - com temor e humor, pânico e esperança -, quero agradecer aos muitos ensaístas que aceitaram o repto, dialogando nos Seminários, participando nos debates, publicando os seus textos nos libretos ou na revista, e ainda a todos os pesquisadores, colegas, alunos, amigos que entraram neste diálogo, enviandome sugestões de livros e filmes, intuições, comentários. Trabalhámos todos muitíssimo, 
mesmo se ficámos com a consciência de que a representação e o imaginário do fim é um tema realmente inesgotável, e exige que continuemos a interrogá-lo até ao fim dos tempos...

Terminados seis anos de estudo, justifica-se um ano sabático, para deixar repousar as inquietações levantadas. Mas, se o tema é inesgotável, custa pensar um fim dos Seminários do Fim do Mundo, como se a inquirição pudesse ter atingido algum telos ou Juízo Final. Double bind: é preciso parar, é impossível parar. Por isso, em vez de continuar ou encerrar estes Seminários, prefiro pensar um estranho tertium. Em 1975, o Collège de 'Pataphysique, que explora e glosa a obra de Alfred Jarry, decidiu entrar em «ocultação»: deixou de se manifestar publicamente, sem contudo deixar de existir. Agrada-me sobremaneira esse registo ambíguo, que finta ao mesmo tempo a ideia de «continuidade» e a ideia de «fim», levando o Collège a uma (in)existência virtual, isto é, simultaneamente existindo e não existindo. Neste mesmo sentido, declararei dentro em pouco, não o fim nem a continuidade, mas a Ocultação dos Seminários do Fim do Mundo.

Dito isto, que «saldo» destes trabalhos resta fazer? De forma terrivelmente económica, enfatizo pelo menos a pluralidade de linguagens interrogadas e de linguagens interrogantes: nestes seis anos de trabalho, encontrámos o fim do mundo na literatura e no cinema, na banda desenhada e na música, na pintura e nos videojogos; convocámos ferramentas dos estudos literários, da antropologia, da teologia, dos estudos fílmicos; descrevemos o fim do mundo como terror, resolução da História, piada, pesadelo, desejo secreto. E talvez possa sistematizar estas descrições do fim em duas grandes linhas: o imaginário e a representação do fim.

Ou seja: por um lado, o fim imaginário - que se antevê, se profetiza, se espera ou receia. Do big crunch à colisão da Terra com um planeta como o popular Planeta X ou a Melancholia de Lars von Trier; das catástrofes descritas no Apocalipse às distopias de P.D. James, Margaret Atwood ou Cormac McCarthy; dos sonhos individuais, incluindo o trabalho da antevisão da morte própria, ao imaginário de revoluções políticas, transformações radicais do mundo «tal como o conhecemos»; dos muitos cenários de catástrofe ecológica à perspectiva de uma migração para novos planetas - em suma: não nos cansamos de alucinar fins possíveis, com gozo e terror. 
Por outro lado, não o imaginário, mas a representação do fim. Porque existem fins reais em acontecimentos como o 11 de Setembro de 2001, os conflitos militares no Médio Oriente, a morte de tantos migrantes africanos no Mediterrâneo, a ascensão de movimentos de extrema direita, a escalada de formas de racismo e de homofobia, as políticas anti-emigração de Donald Trump, a destruição do habitat de povos indígenas da Amazónia no governo de Jair Bolsonaro, a instalação do Antropoceno. E é por esses fins serem tão reais - que importa muitíssimo falar sobre eles, resistir.

Pessoalmente, estes seminários permitiram-me coligir materiais, intuições, pistas de trabalho - que gostaria de transformar num longo, longuíssimo ensaio. Dada a complexidade do tema, deveria ser um ensaio de umas 10.000 páginas... E é certo que já escrevi e publiquei alguns artigos sobre o fim do mundo em autores como Fernando Pessoa, Herberto Helder ou Gonçalo M. Tavares; mas confesso também que, do grande ensaio a escrever, ainda não tenho uma única linha, mesmo ao fim destes seis anos. Bem sei às vezes que os livros se fazem rogados, e raramente adianta pressioná-los; outras vezes, quase se escrevem a si próprios, que nem ditados. Veremos.

Resta dizer que uma instituição ocultada pode sempre ressurgir: mesmo o Collège de 'Pataphysique assumiu a sua «desocultação» no ano 2000, voltando a apresentar-se publicamente. Também os Seminários podem voltar a qualquer momento, sob a mesma forma ou um pouco metamorfoseados - talvez como novos Seminários da Origem do Mundo, ou, quem sabe, Seminários da Salvação do Mundo.

Mas tudo isso, claro, se o mundo não acabar primeiro. 
Pedro Eiras é Professor de Literatura Portuguesa na Universidade do Porto, Investigador do Instituto de Literatura Comparada Margarida Losa, Membro da Rede Internacional de Pesquisa LyraCompoetics. Desde 2005, publicou diversos livros de ensaios sobre literatura portuguesa dos séculos XX e XXI, estudos interartísticos, questões de ética. Entre os mais recentes: O Riso de Momo - Ensaio sobre Pedro Proença (2018), [...] - Ensaio sobre os mestres (2017), Constelações 2 - Estudos Comparatistas (2016), Platão no Rolls-Royce - Ensaio sobre literatura e técnica (2015). Entre 2013 e 2018 organizou os Seminários do Fim do Mundo e editou on line os libretos Materiais para o Fim do Mundo. 



\section{Libretos}

XX ILCML

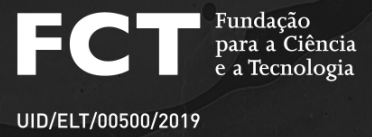

UID/ELT/00500/2019

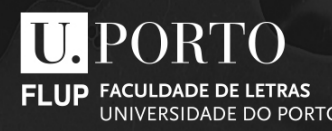

